\title{
THE STUDY ON A LETTER RELATED TO GESER BIOGRAPHY IN GERMANY
}

Abstract. There was a letter relating Geser Biography collected from Germany in 18th century. In this article, it's studied from two aspects that introduce the letter document Khabčiy-un bičig tebče and originate of The Book of Kalmyk Letter. It was concluded that 12 chapters Geser Khan's Biography spread among Kalmyks in the end of 1782.

Keywords: Kalmyk oral tradition; Geser Khan's Biography; Clear Mongolian script (Tod-Mongol bičig)
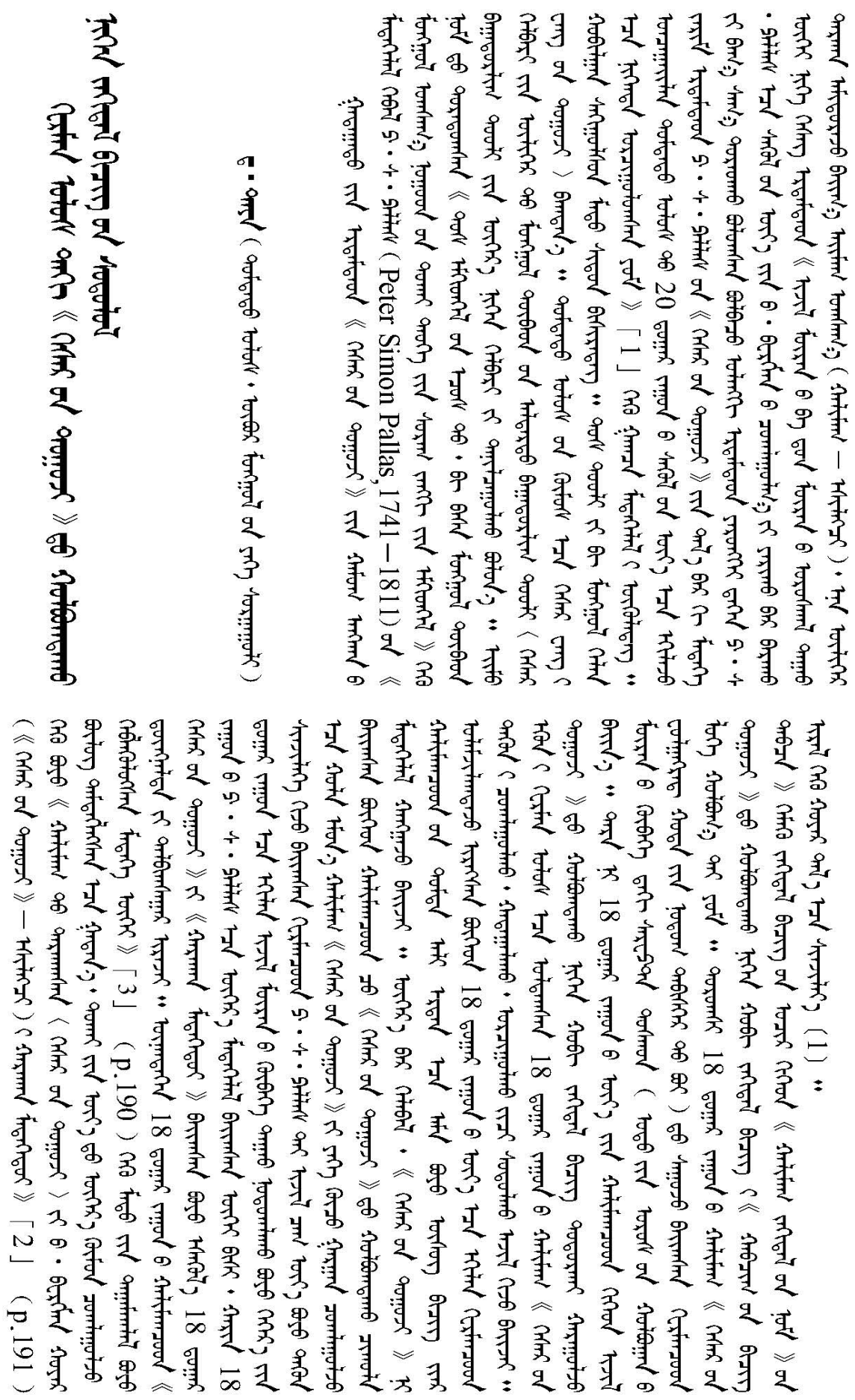


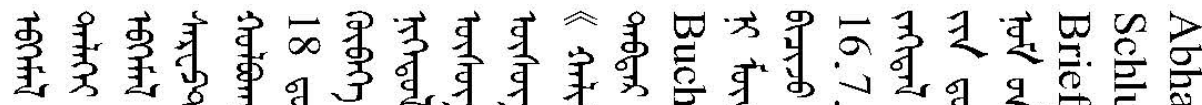

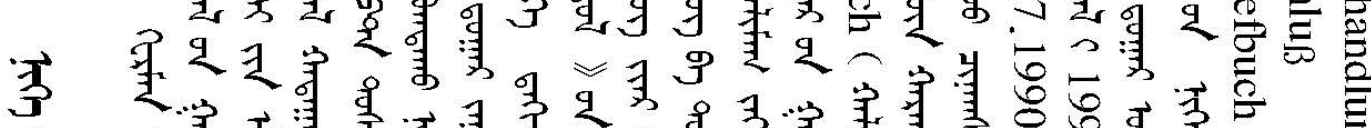

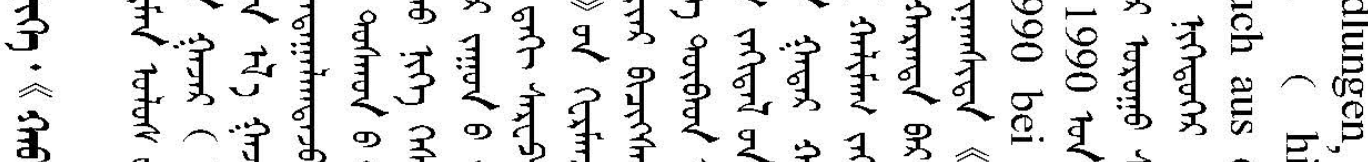

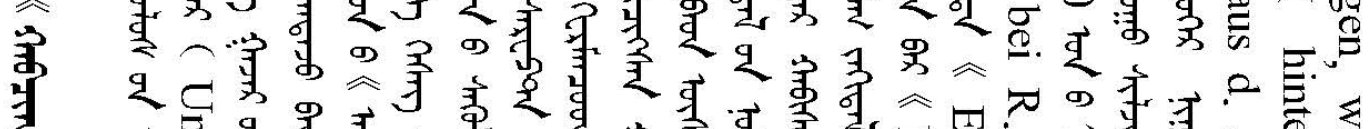

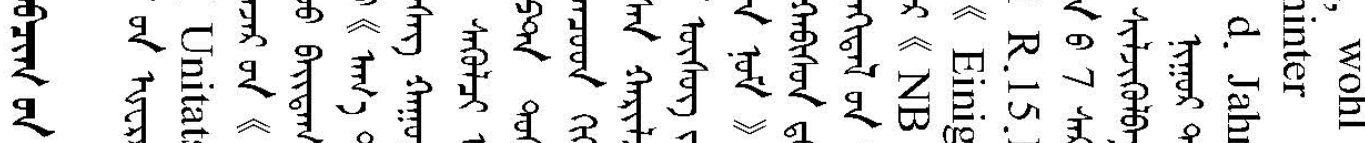

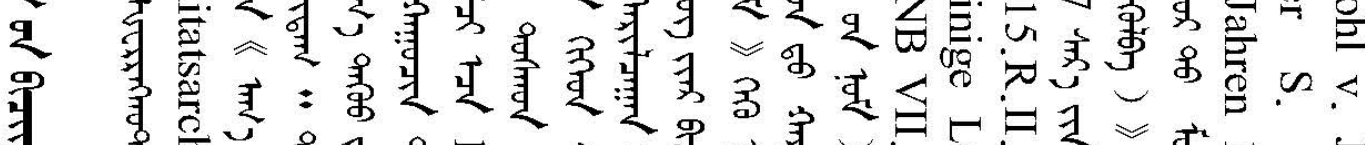

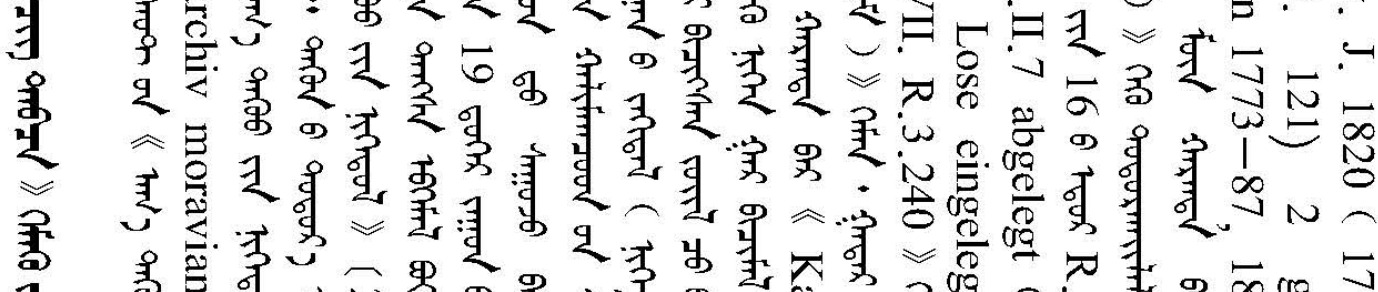

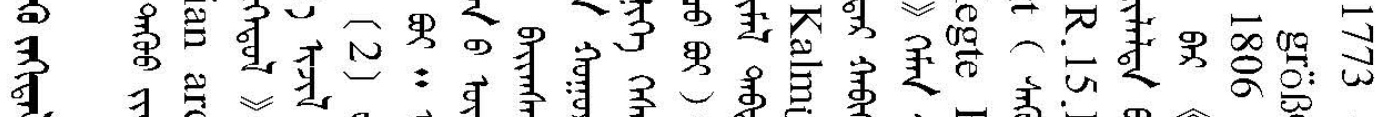

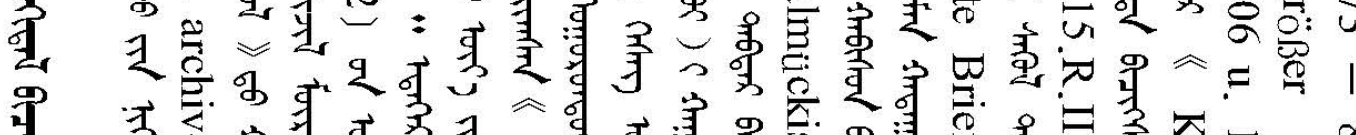

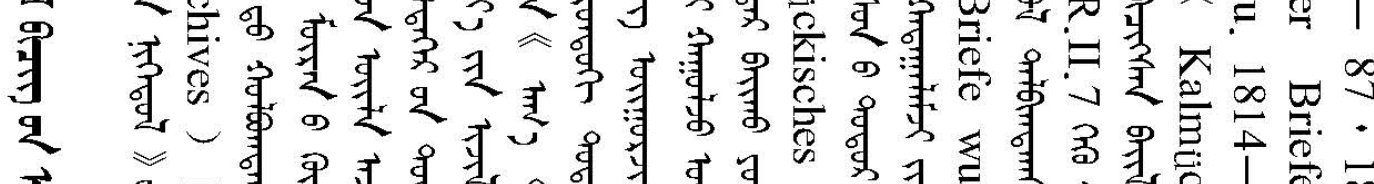

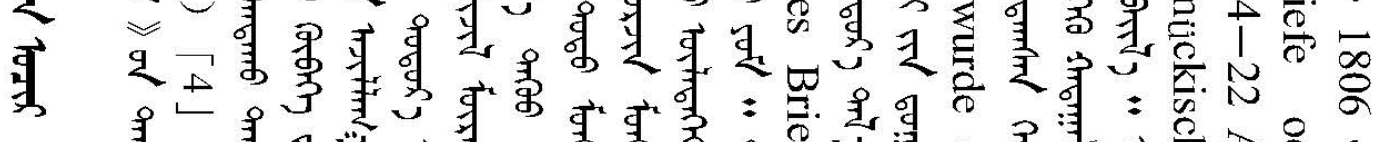

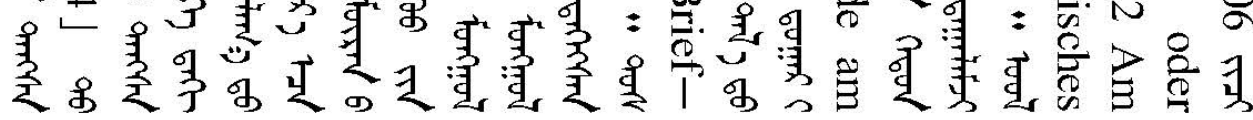

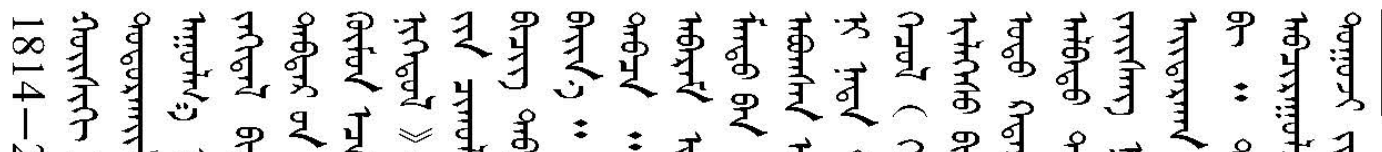

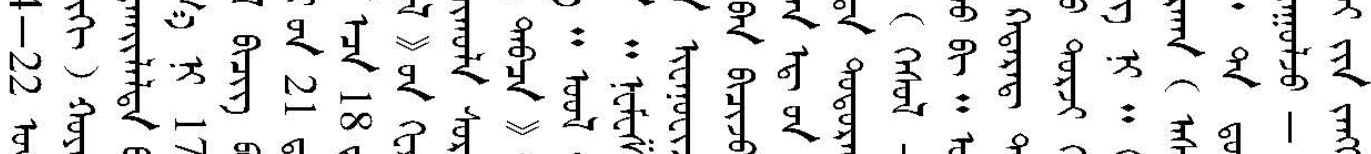

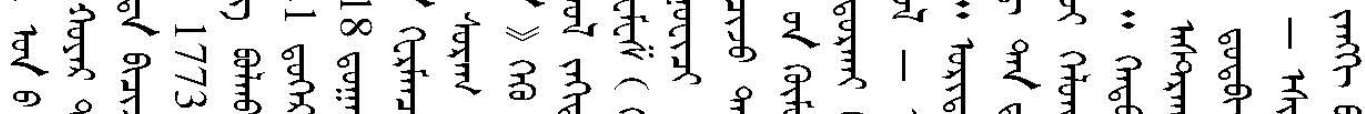

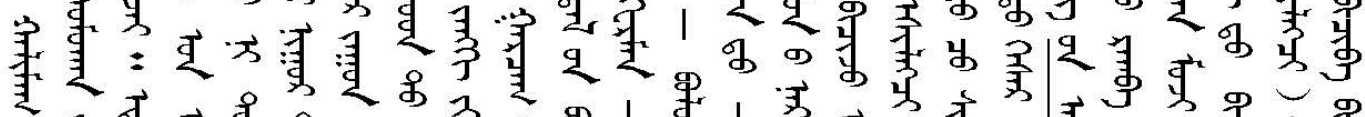

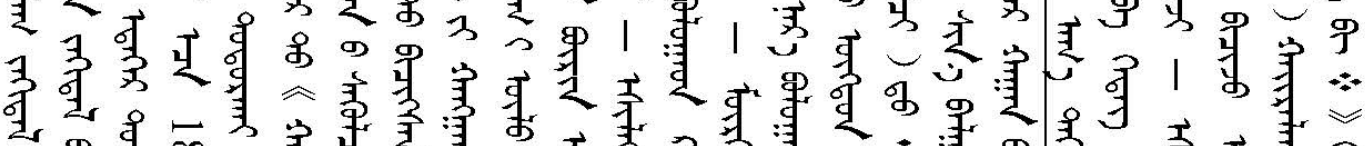

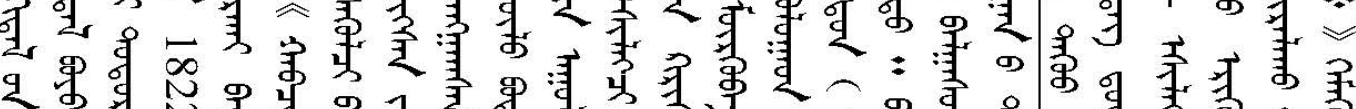

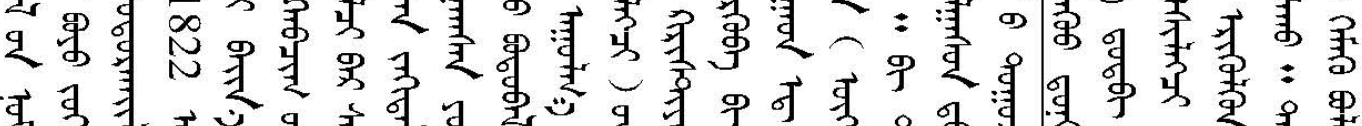

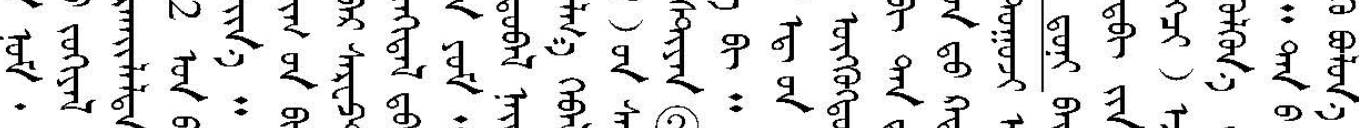

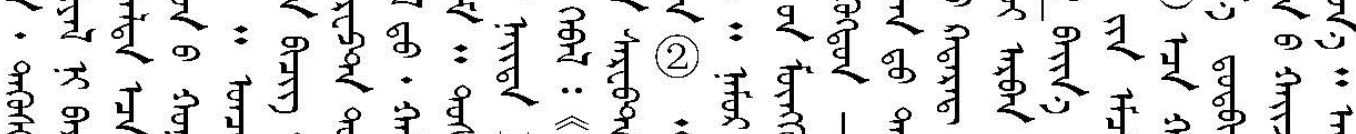

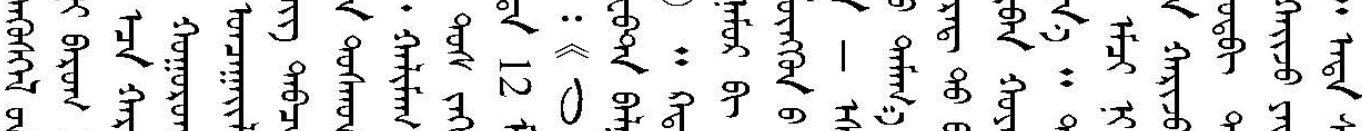

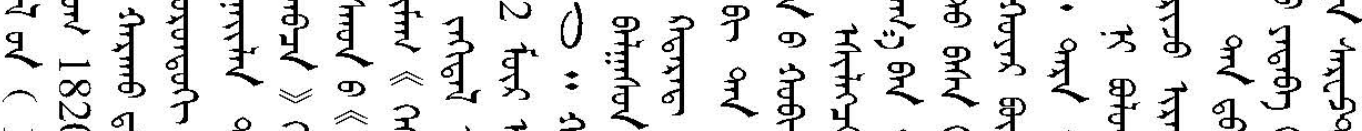

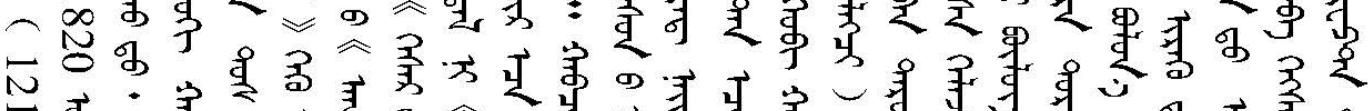

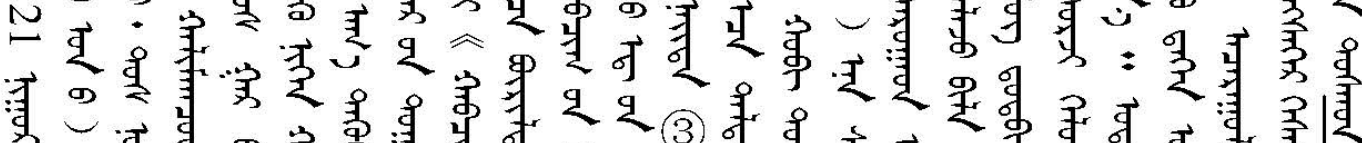

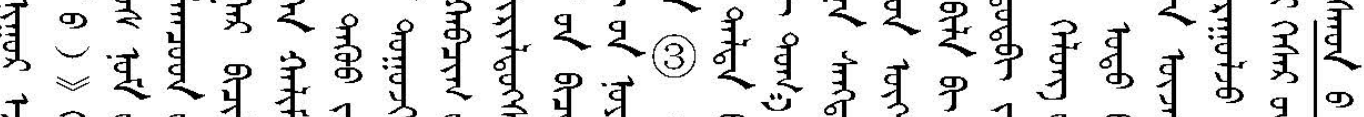

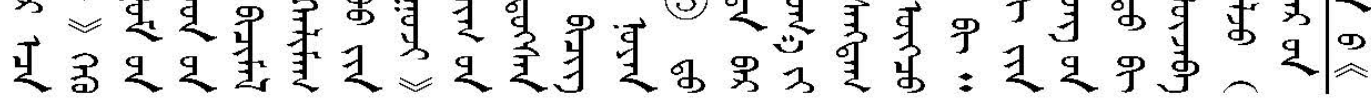




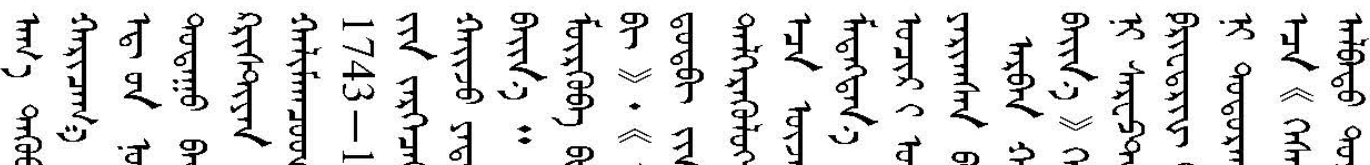

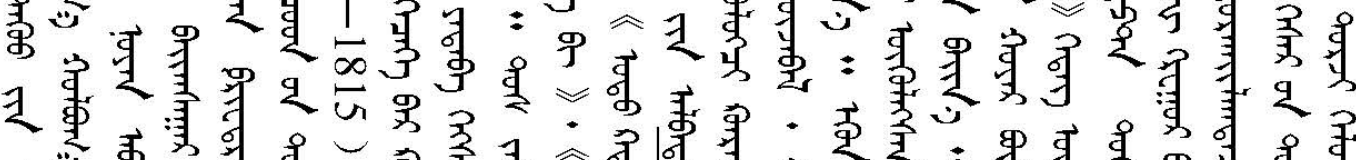

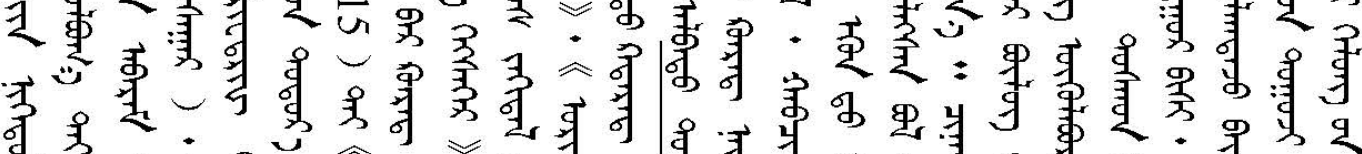

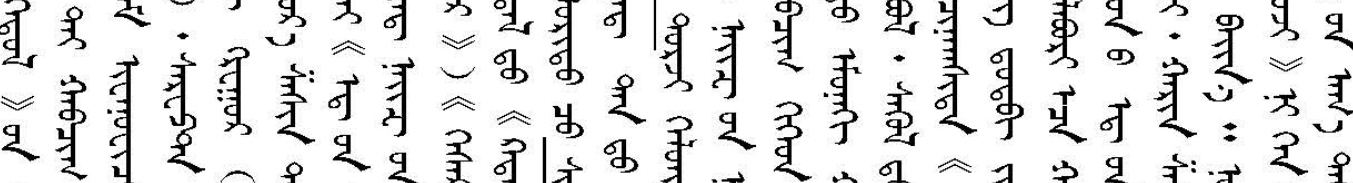

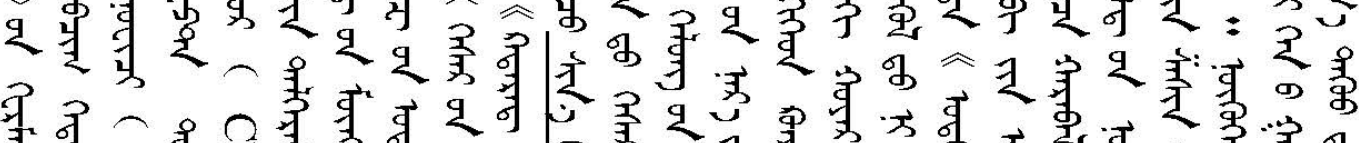

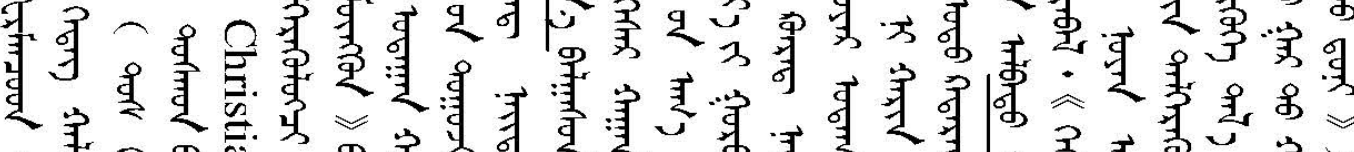

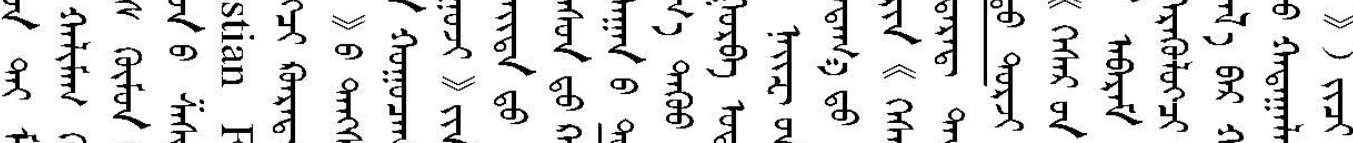

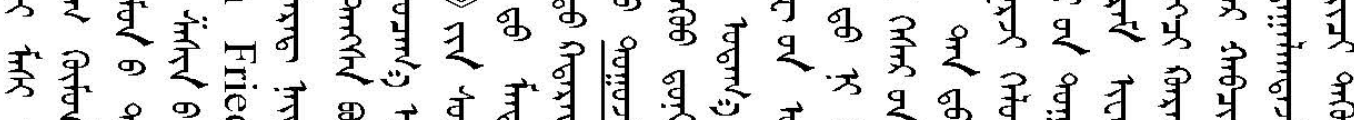

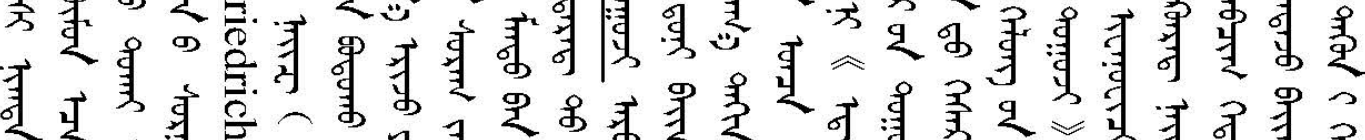

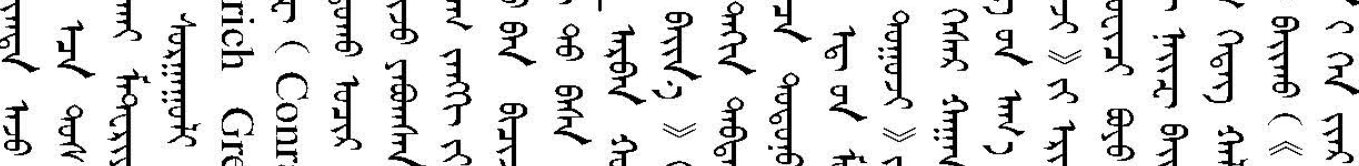

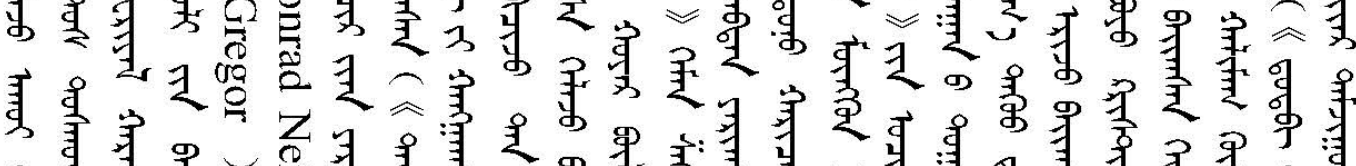

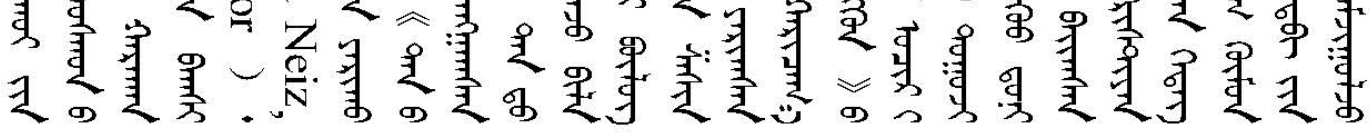

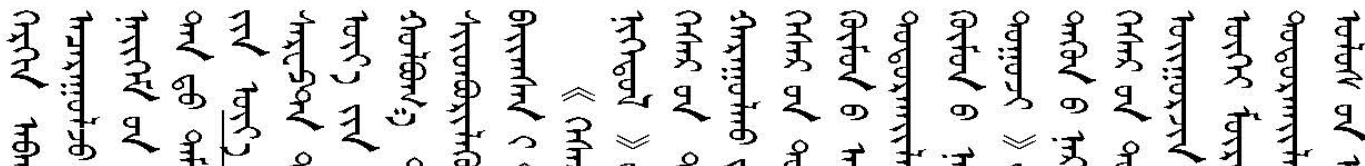

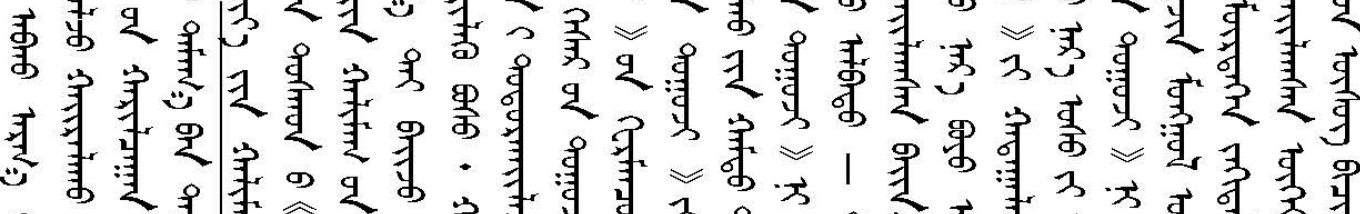

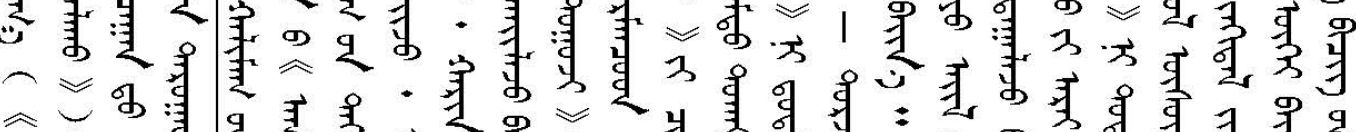

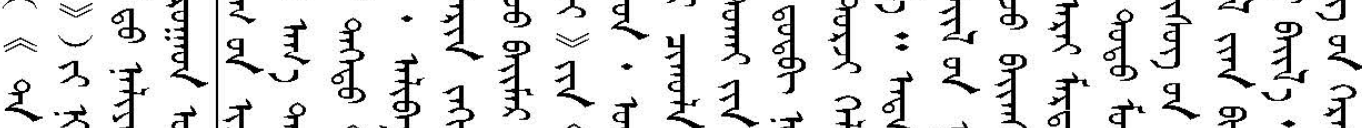

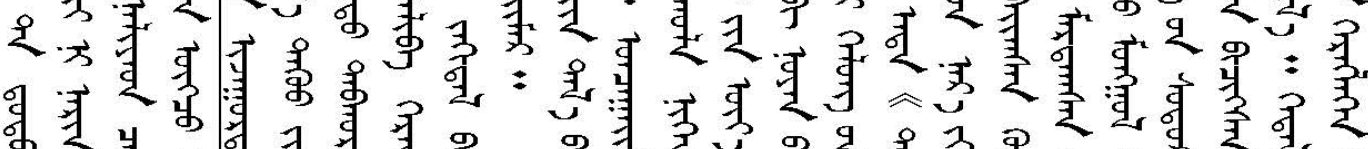

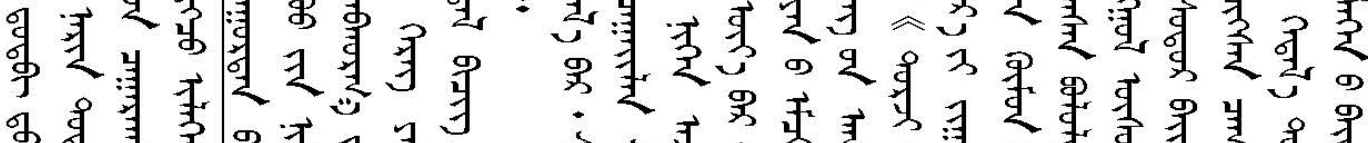

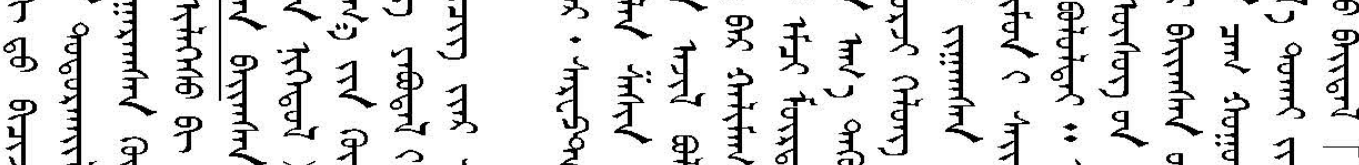

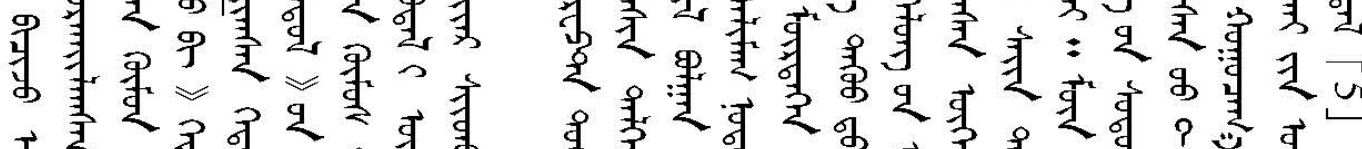

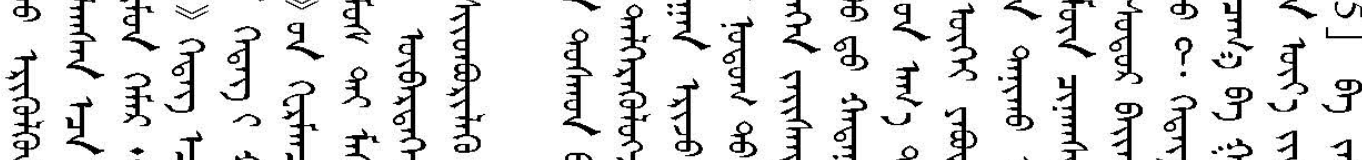

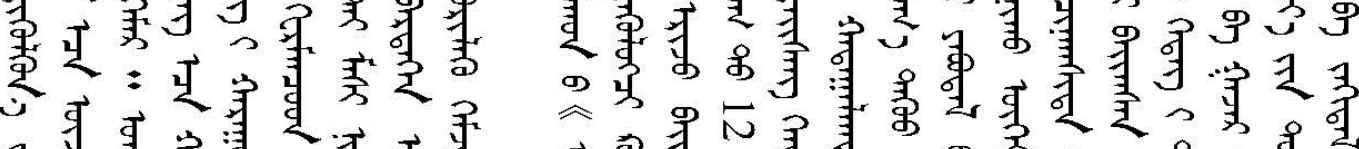

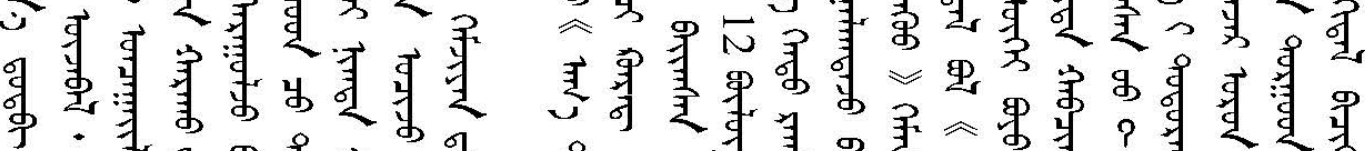

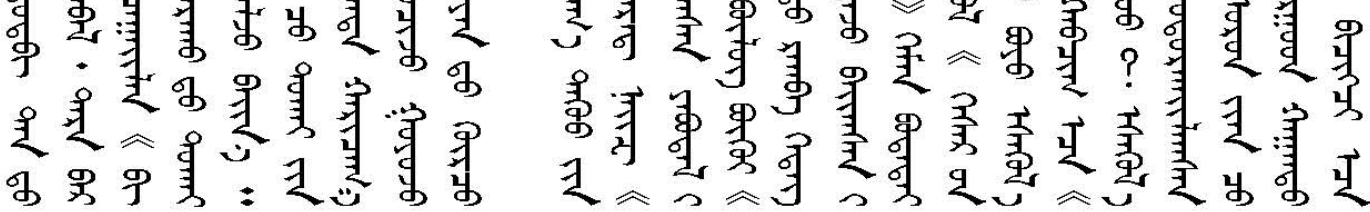




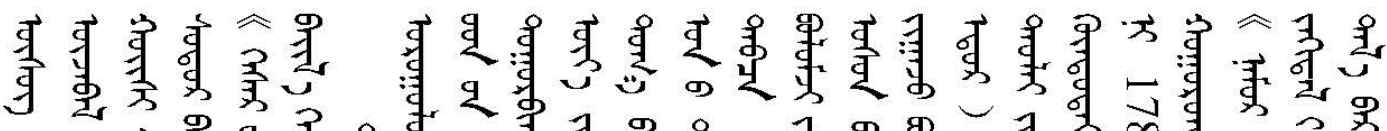

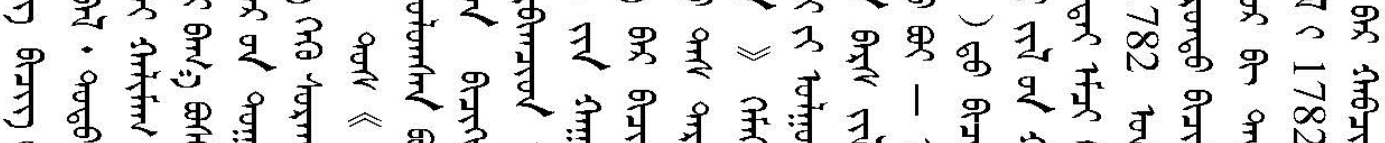

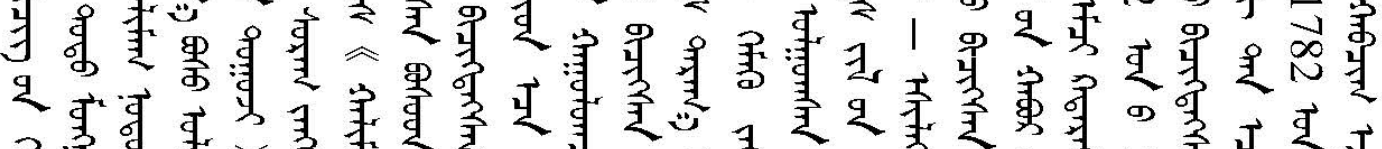

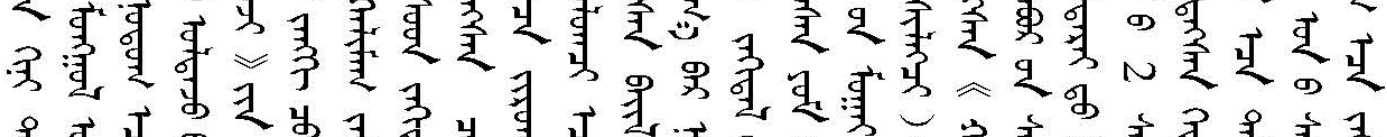

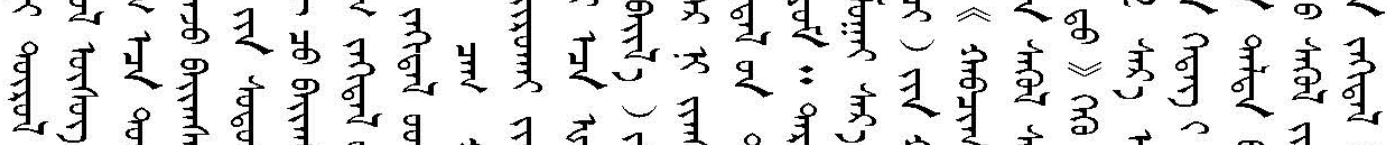

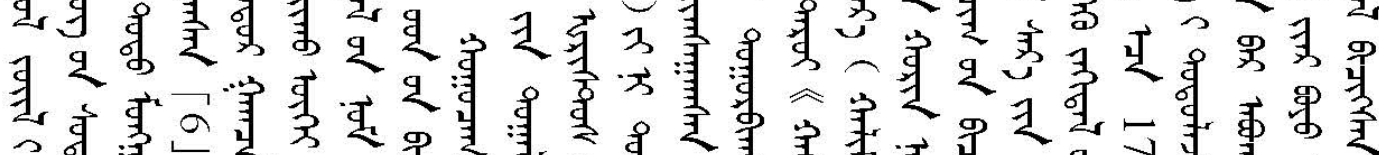

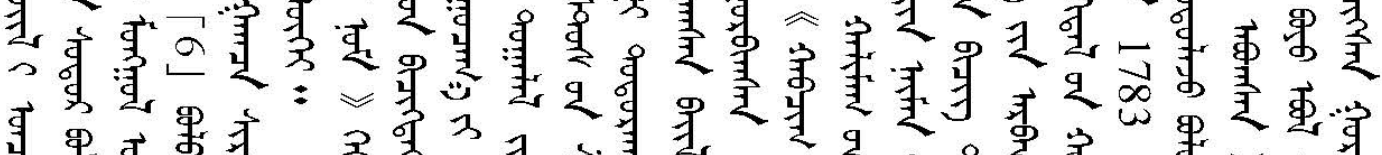

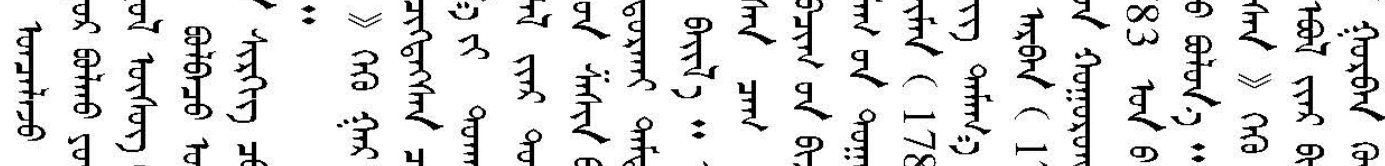

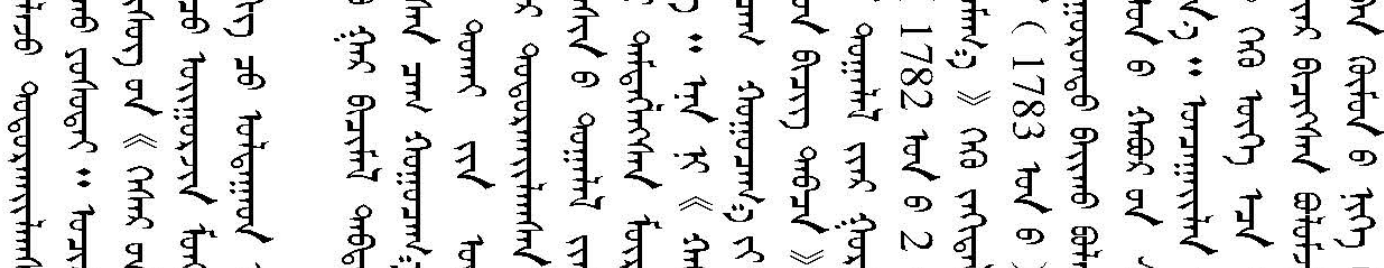

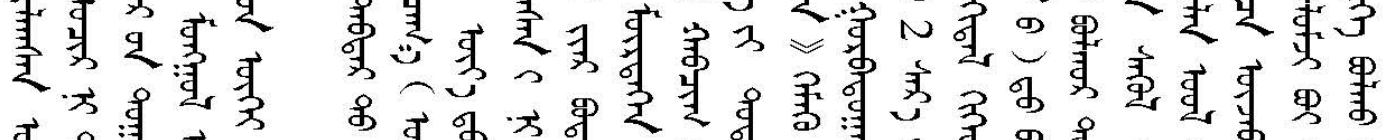

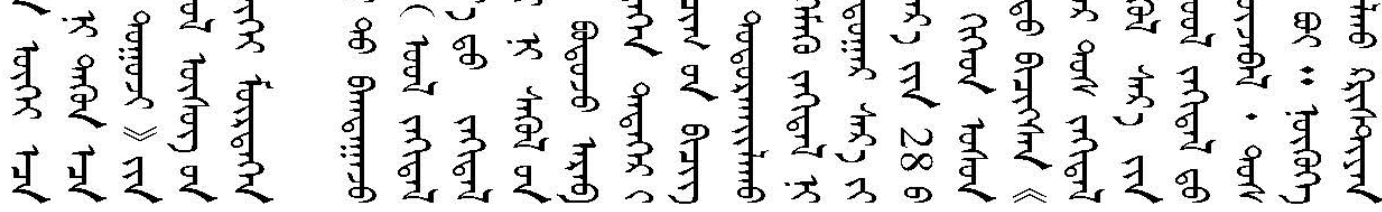

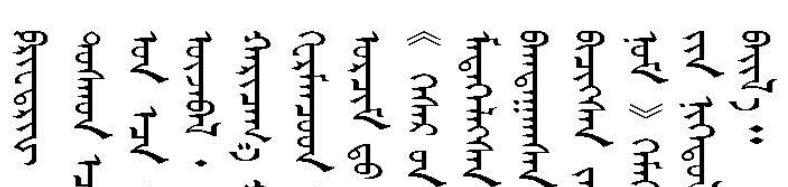

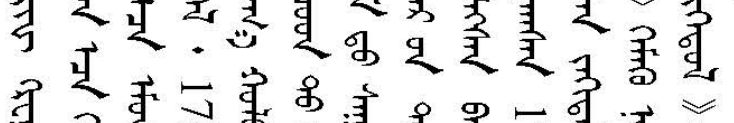

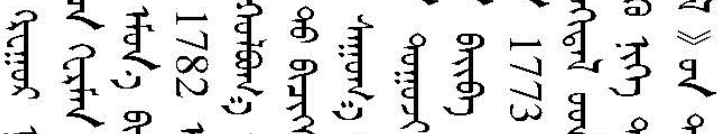

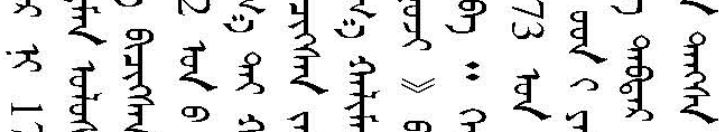

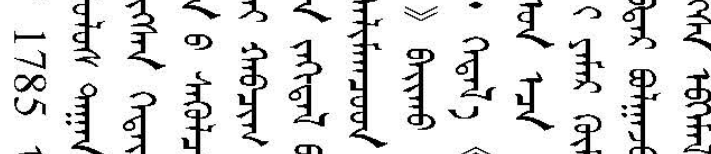
等

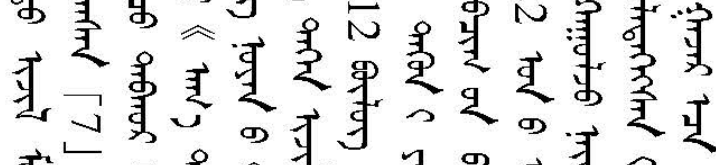

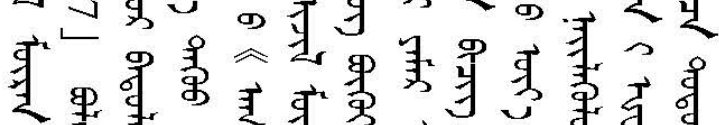

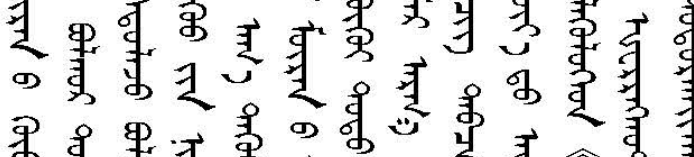

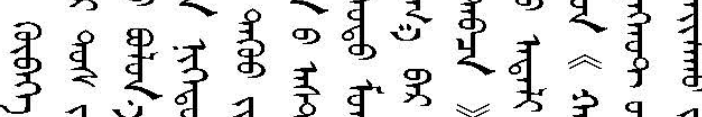

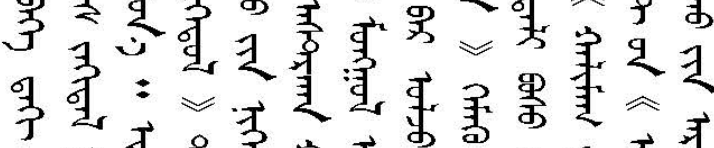

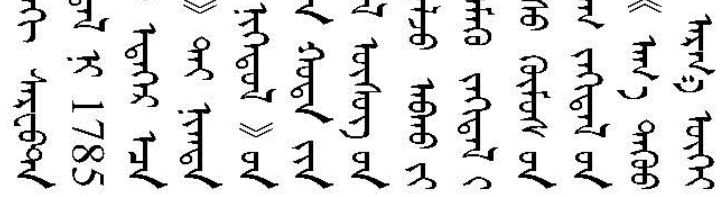

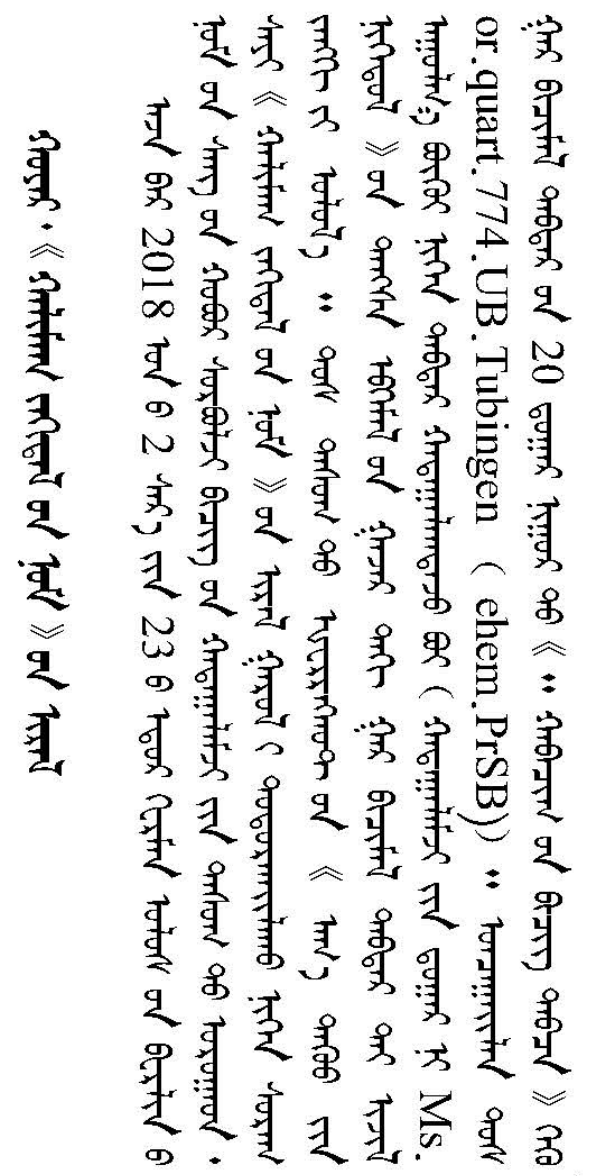




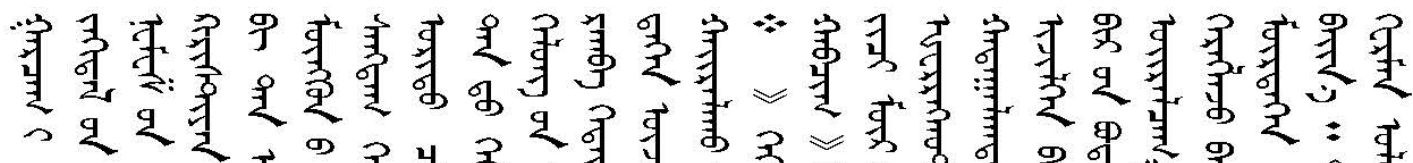

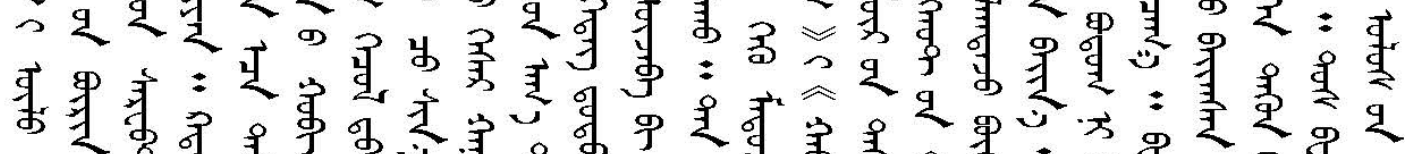

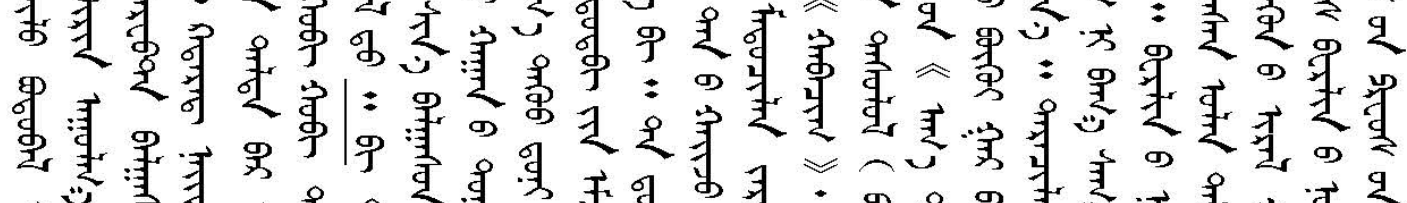

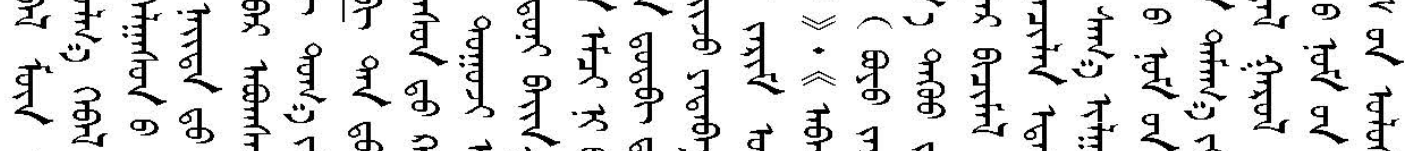

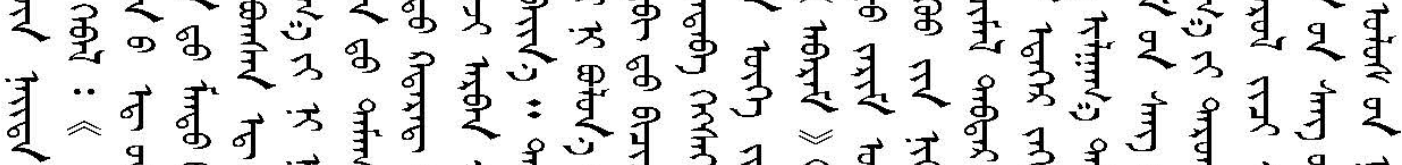

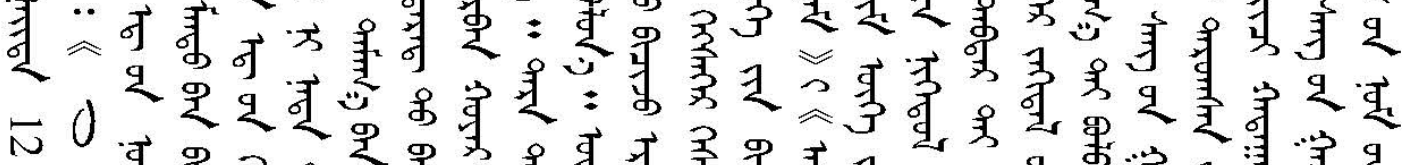

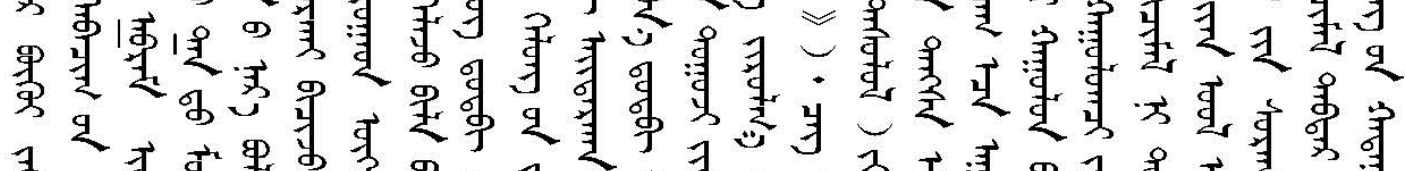

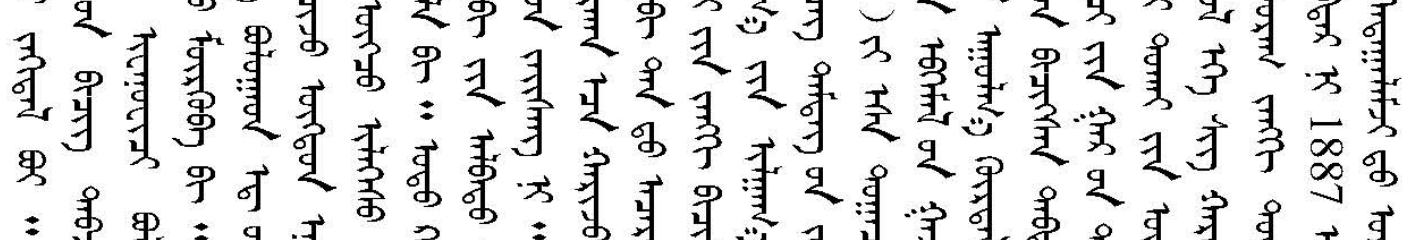

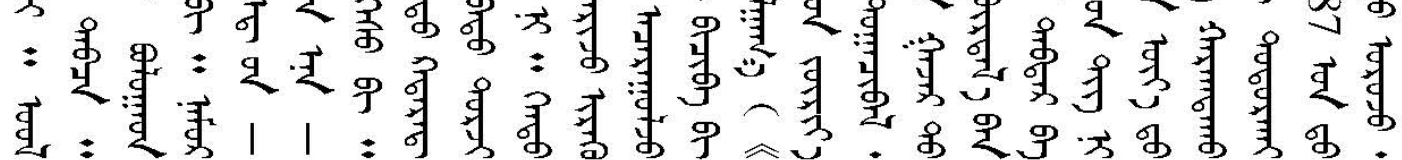

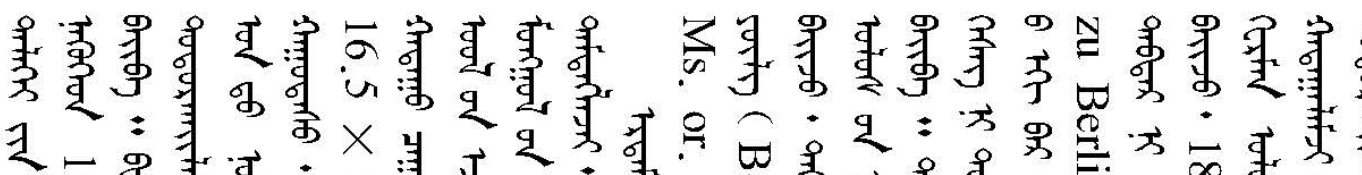

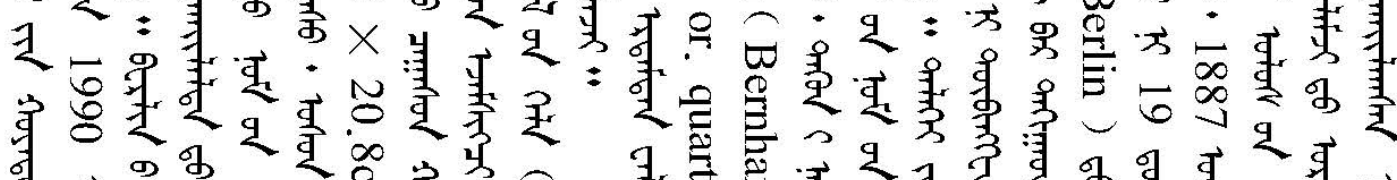

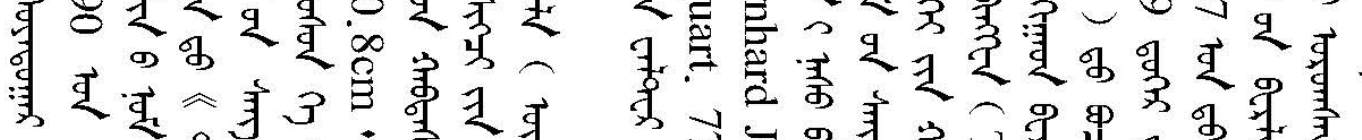

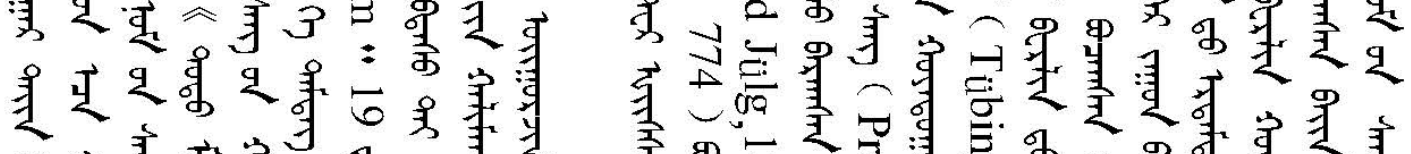

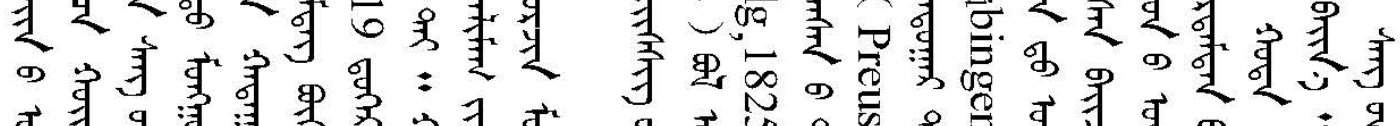

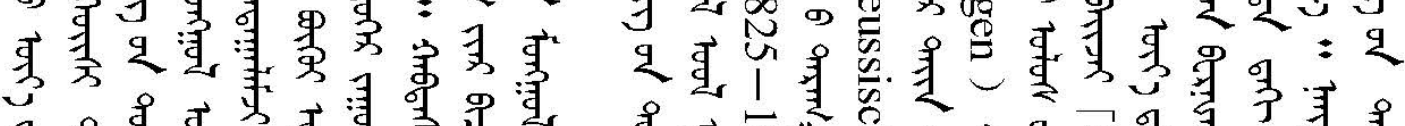

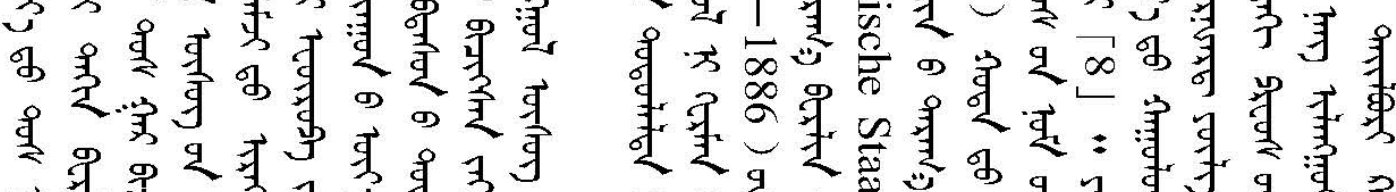

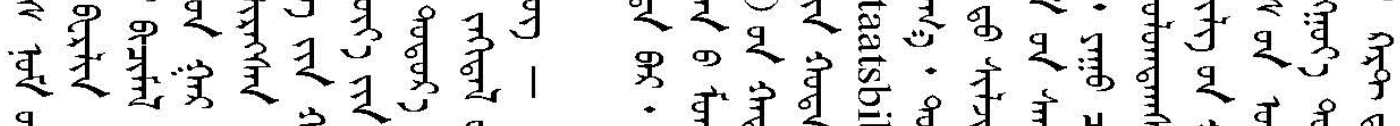

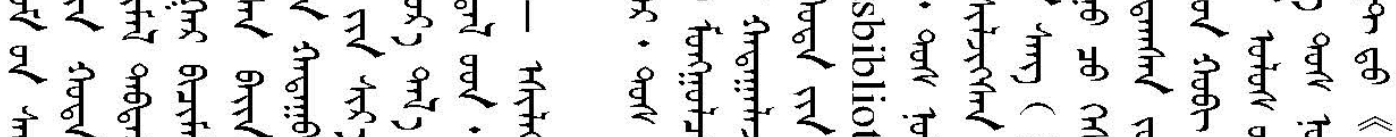

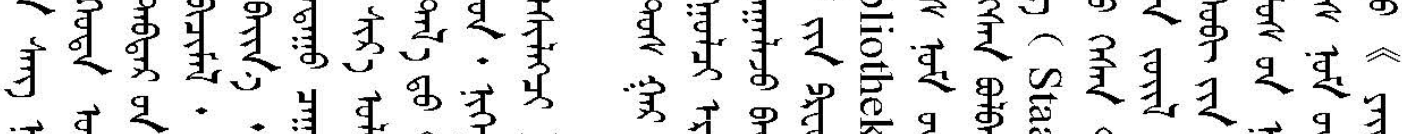

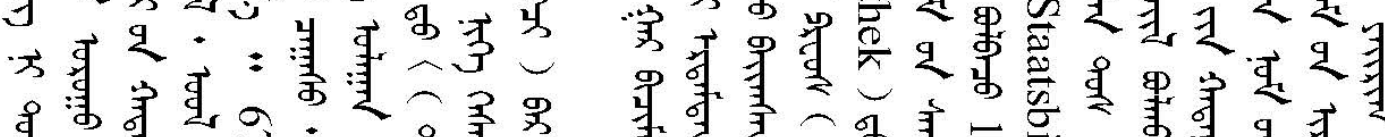

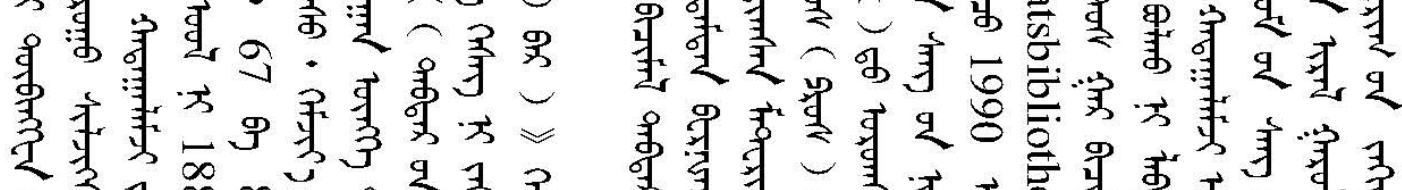

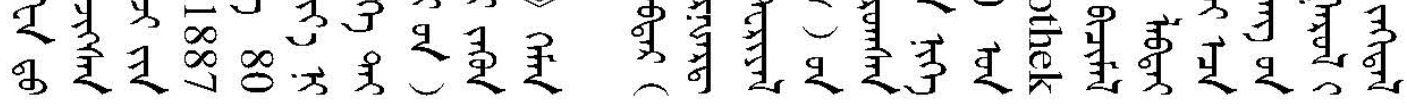




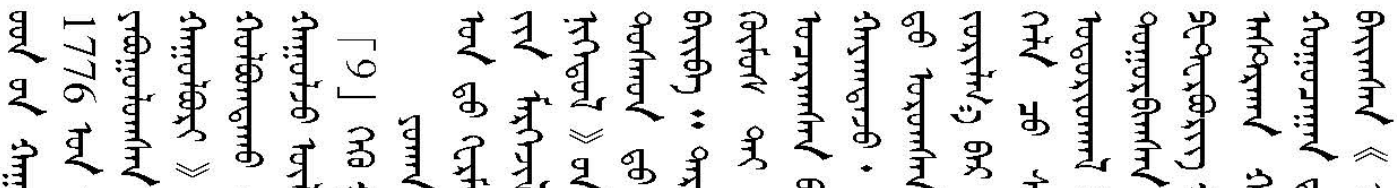

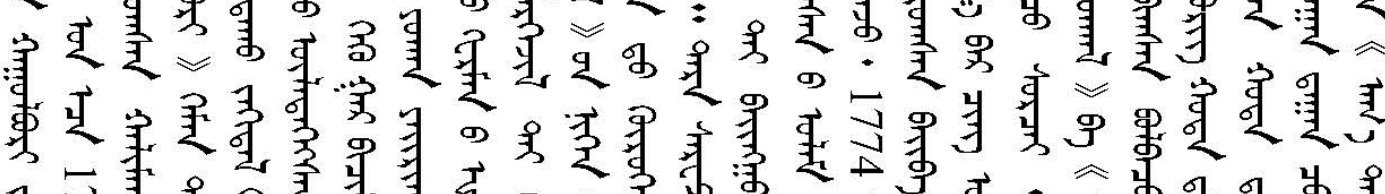

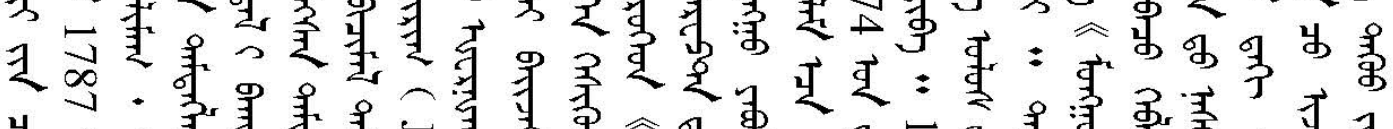

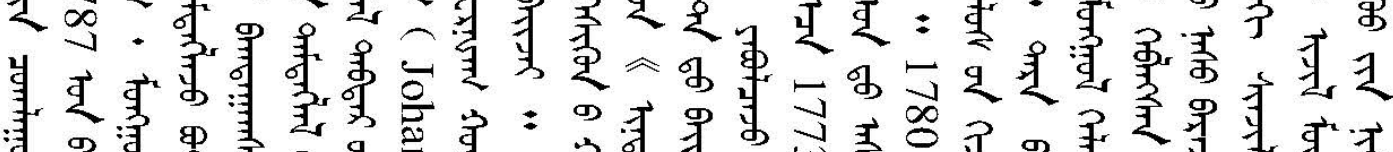

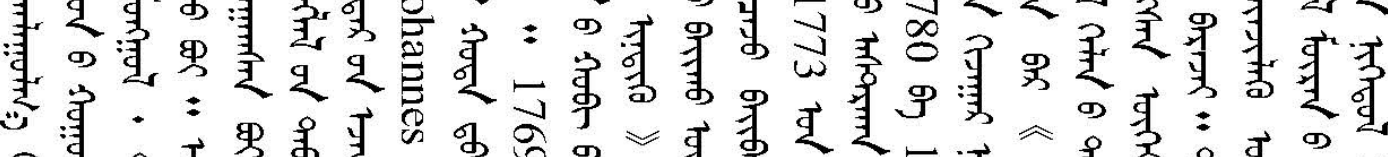

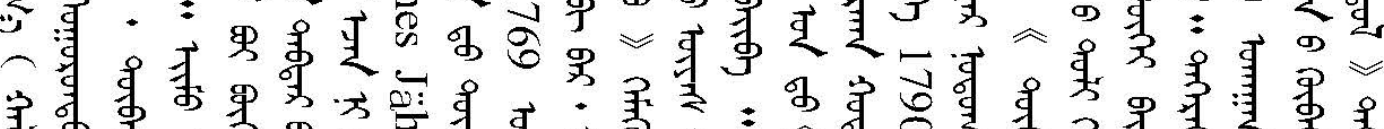

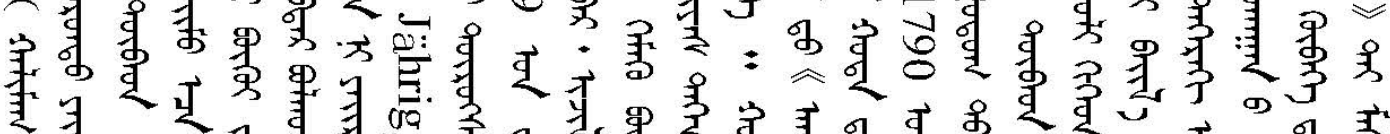

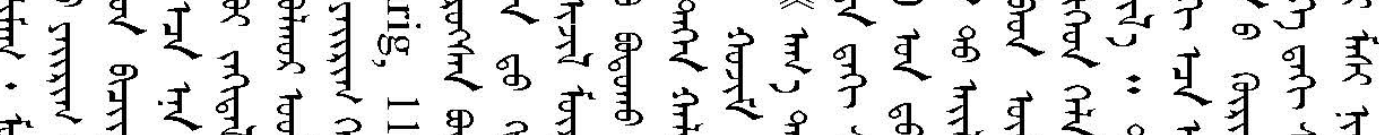

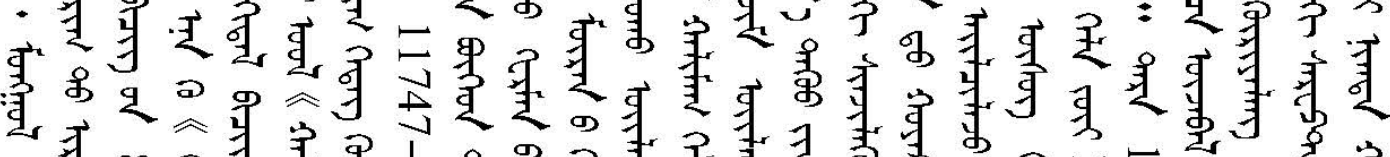

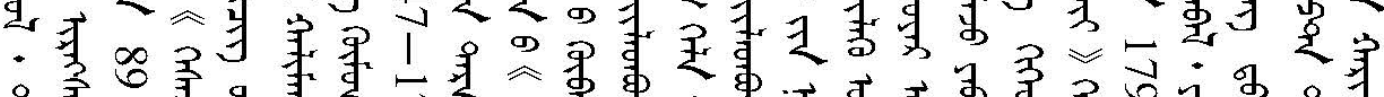

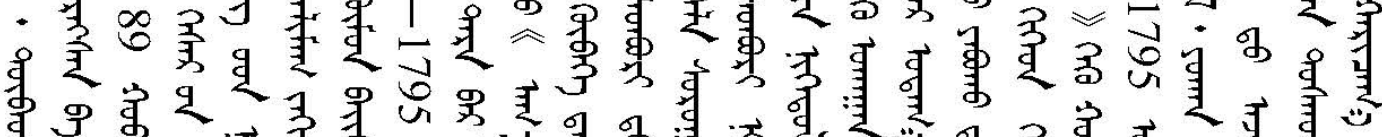

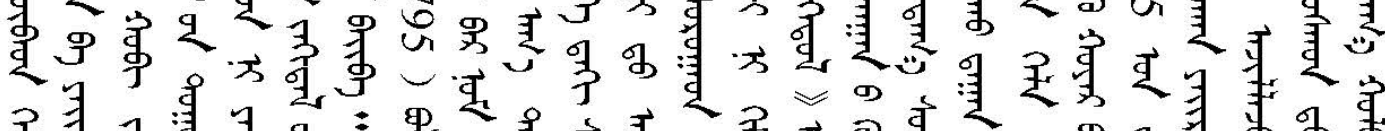

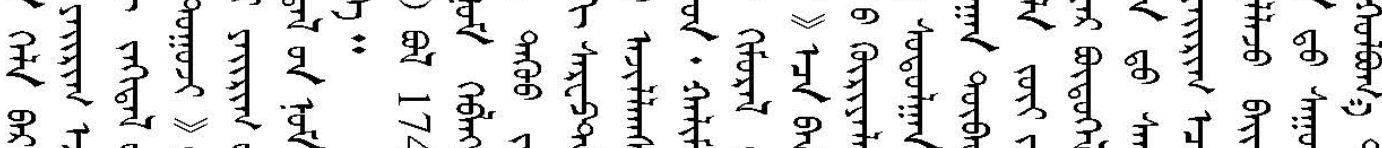

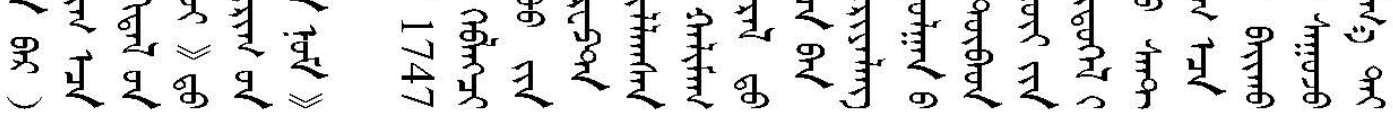

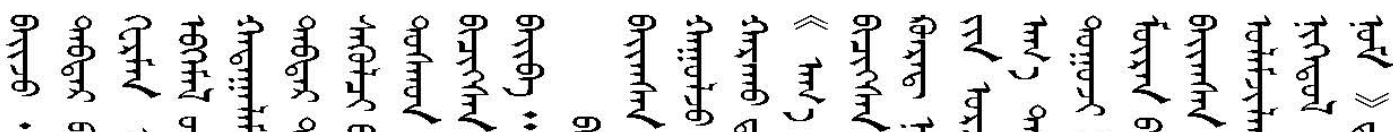

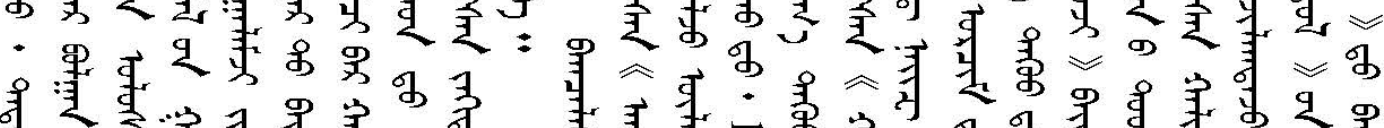

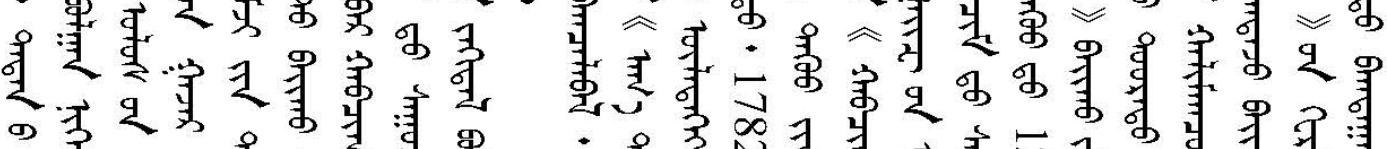

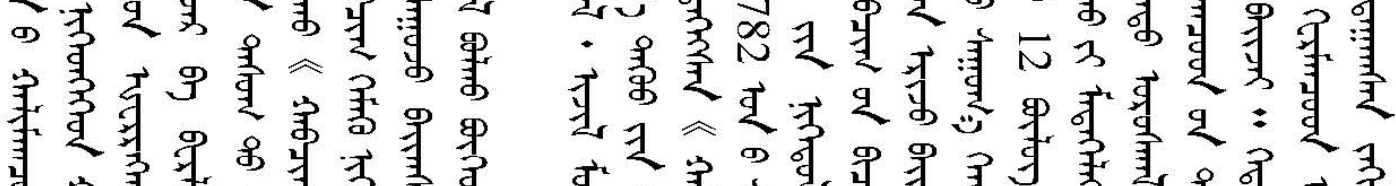

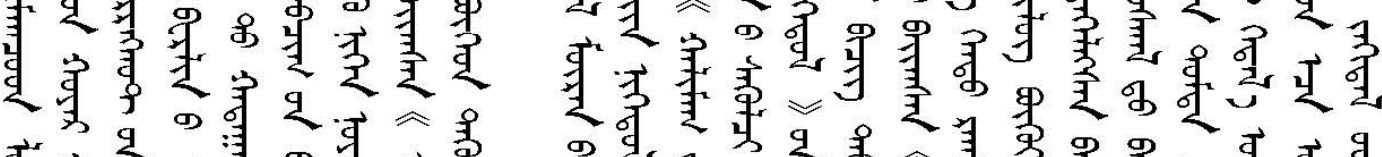

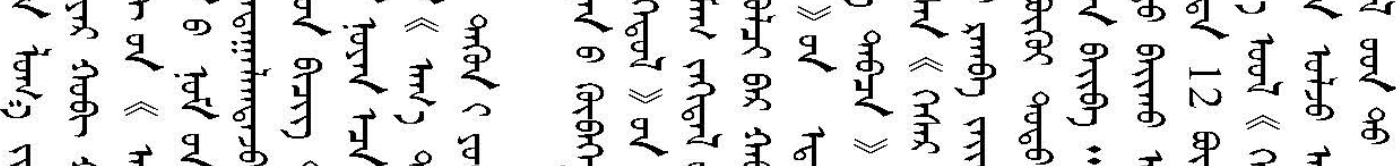

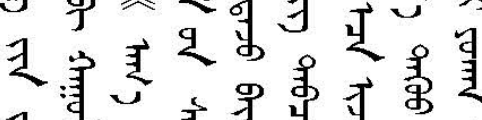

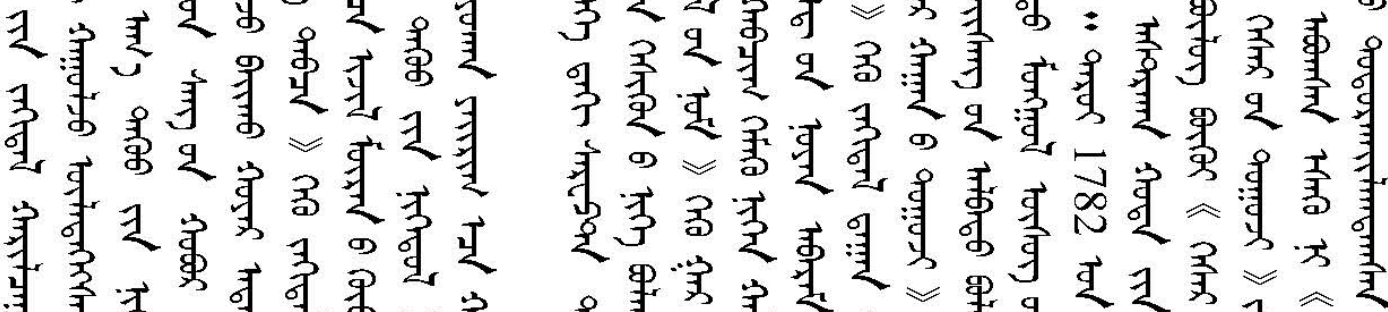

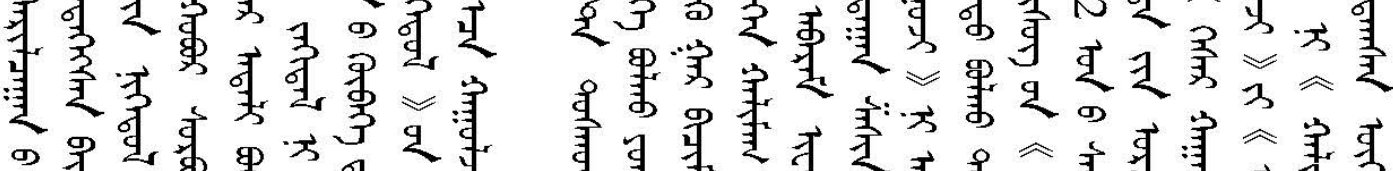

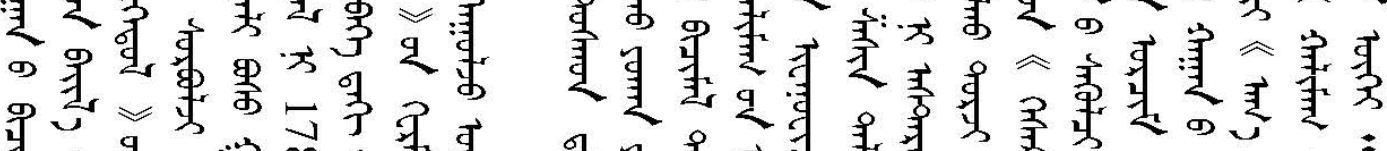

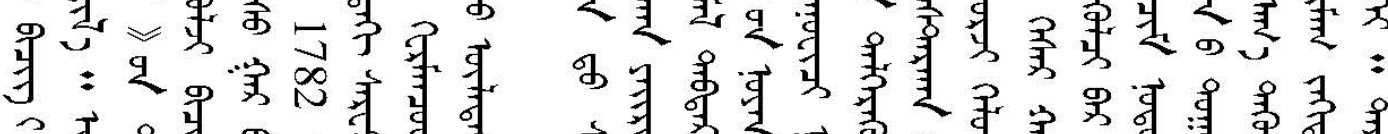

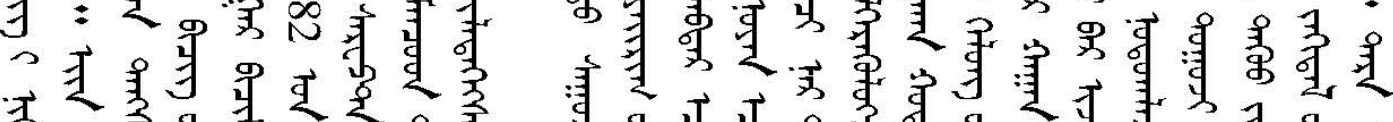

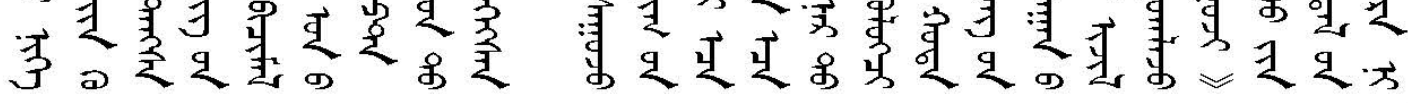




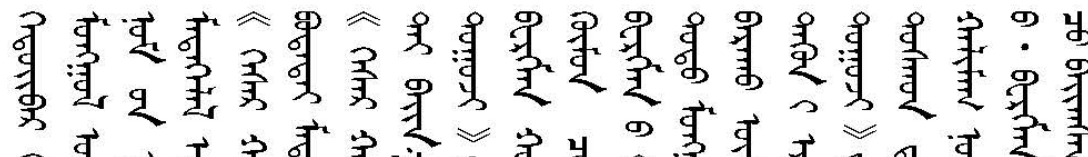

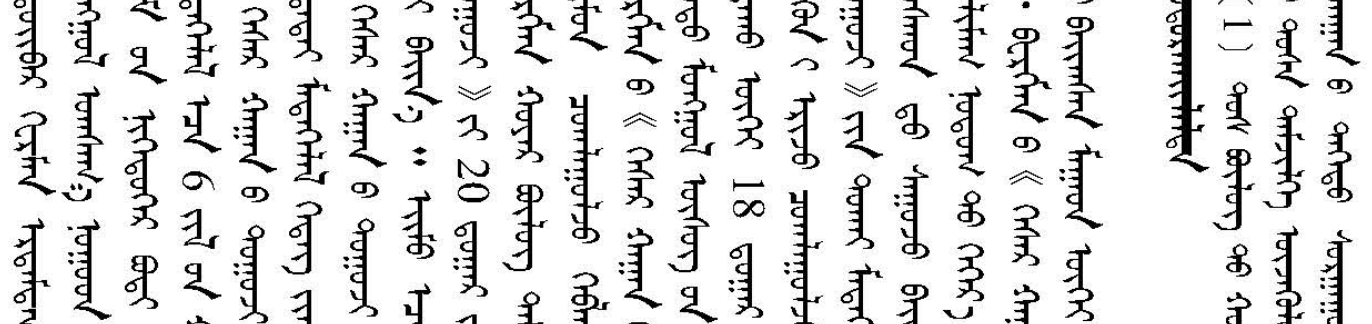

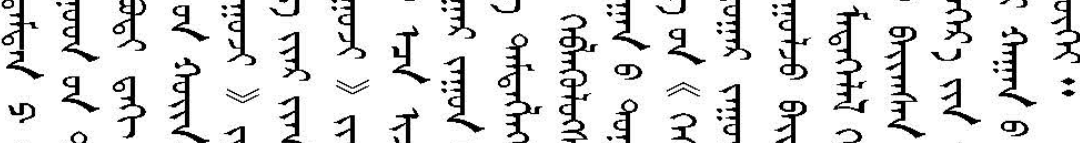

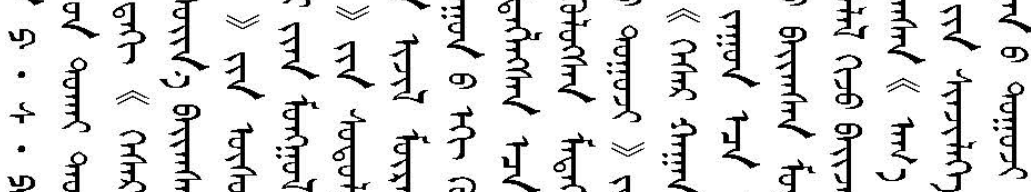

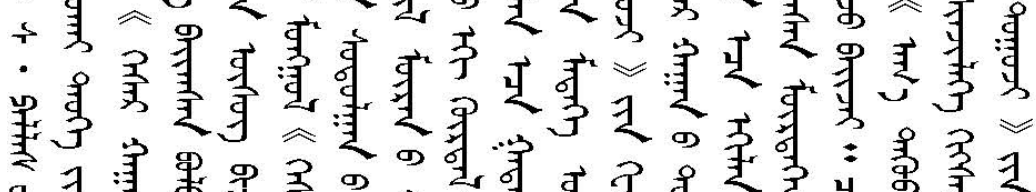

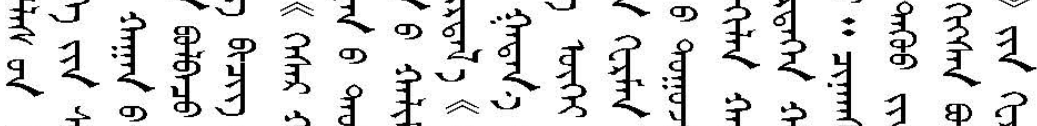

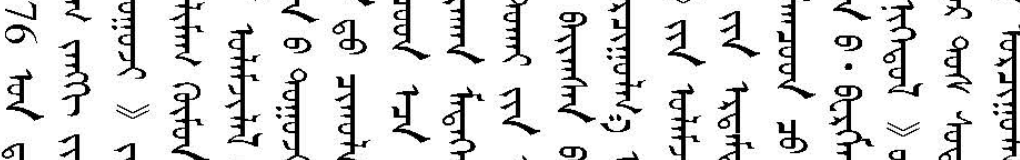

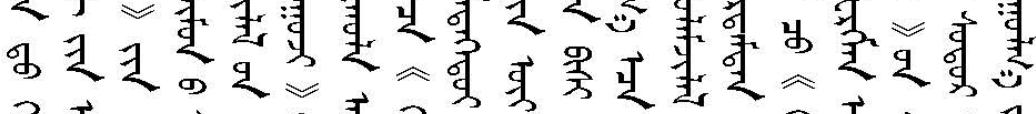

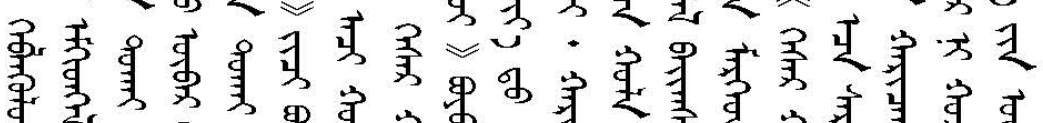

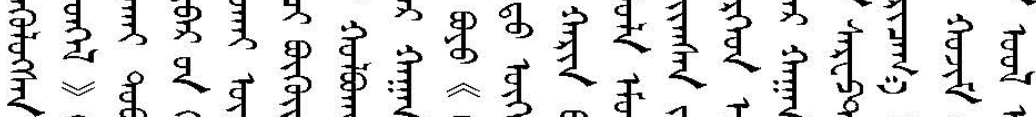

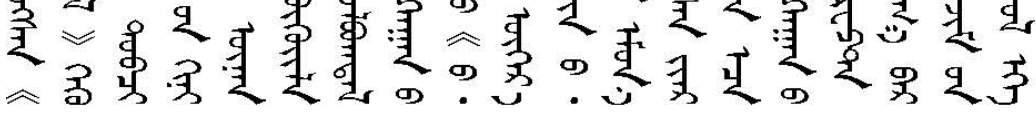

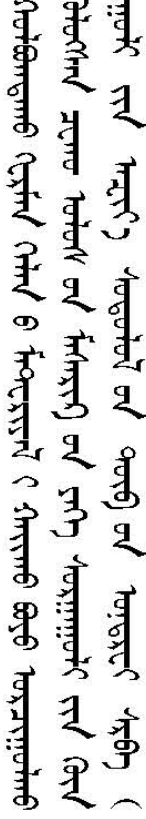

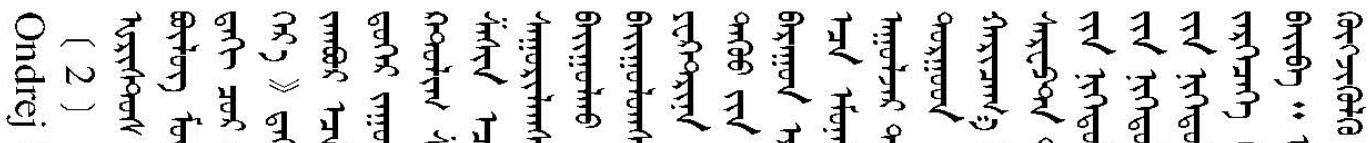

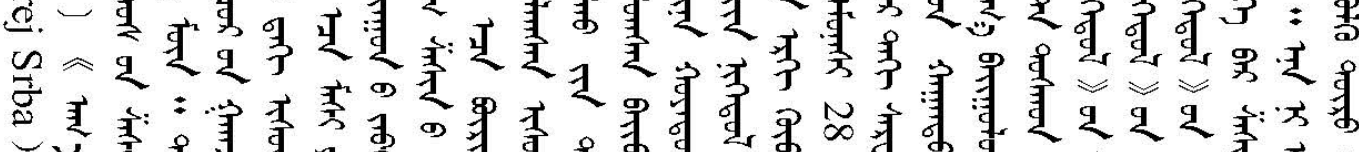

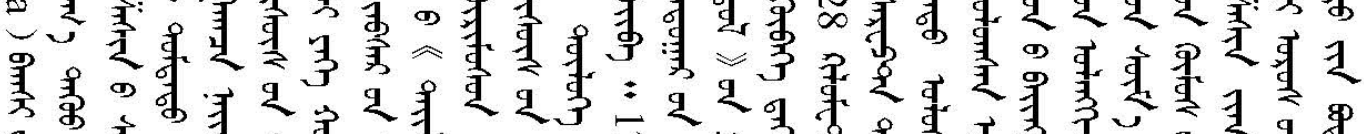

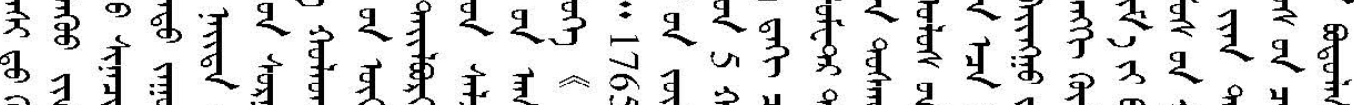

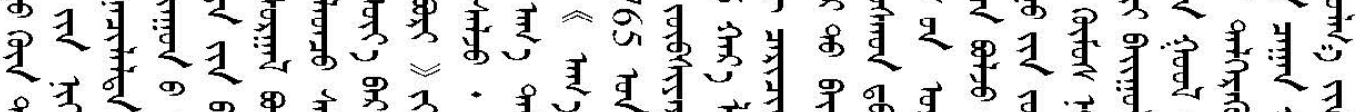

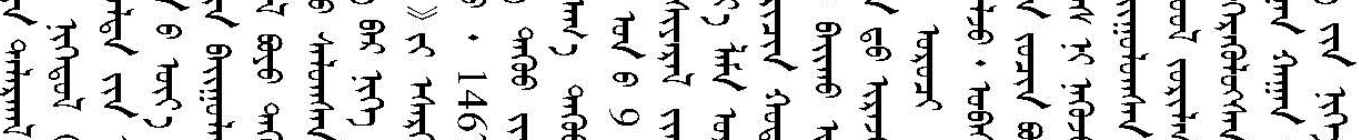

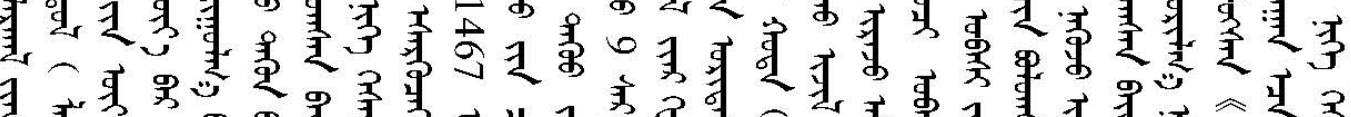

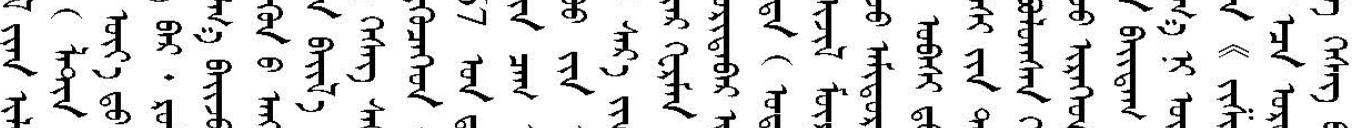

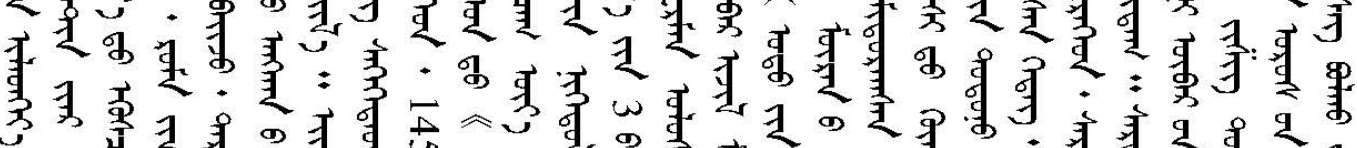

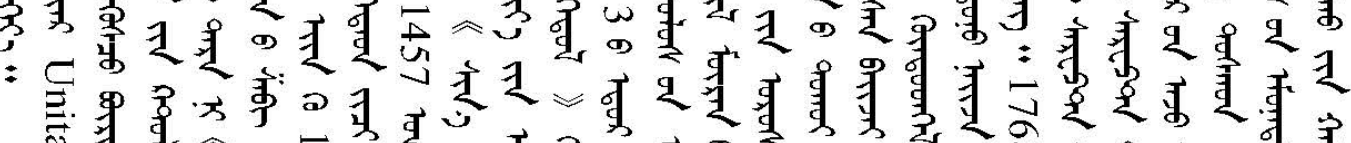

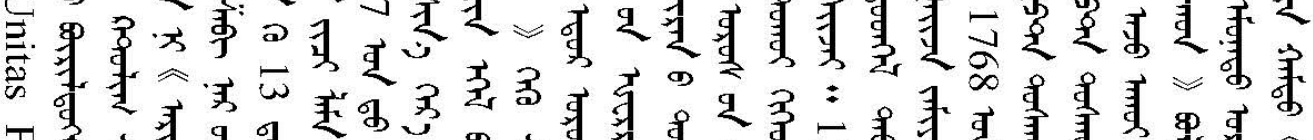

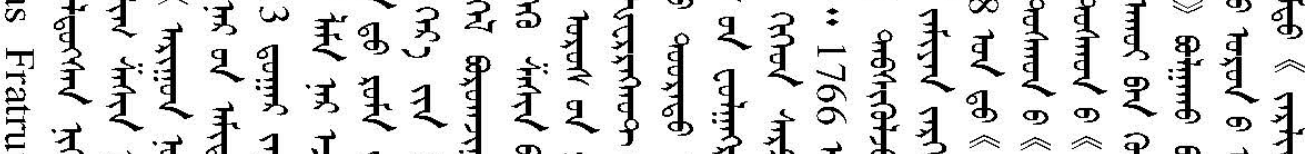

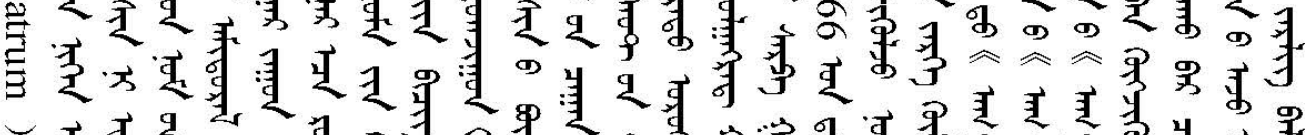

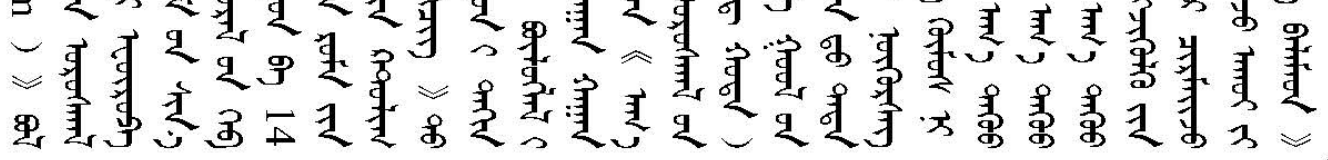




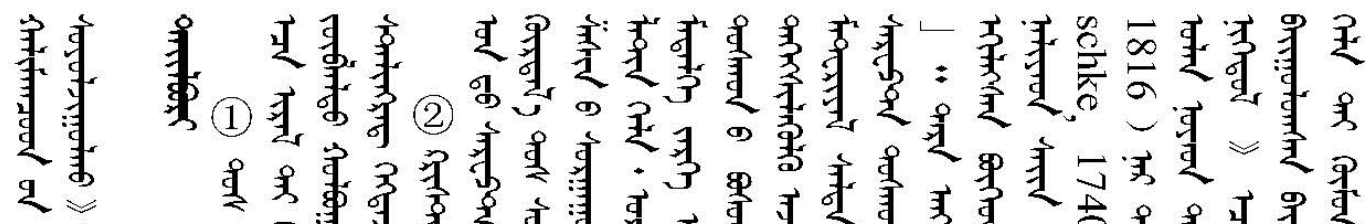

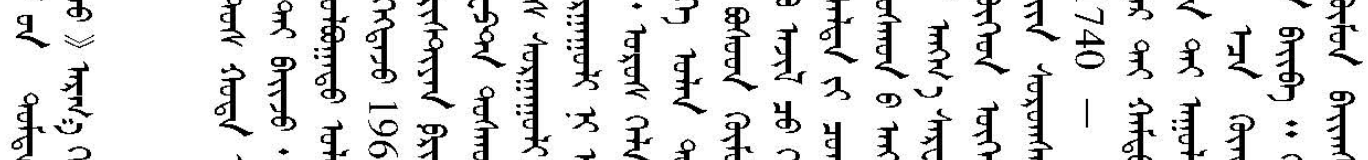

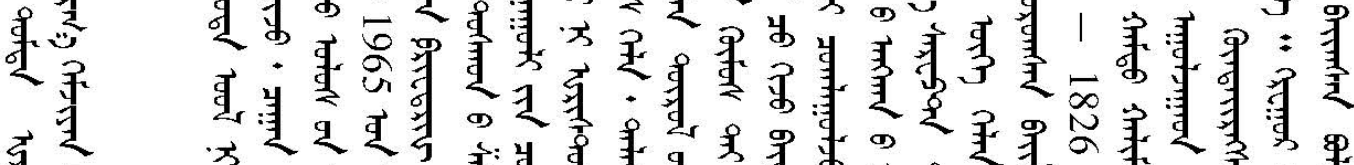

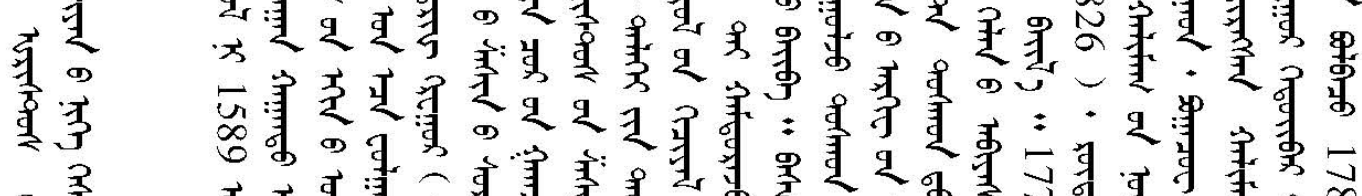

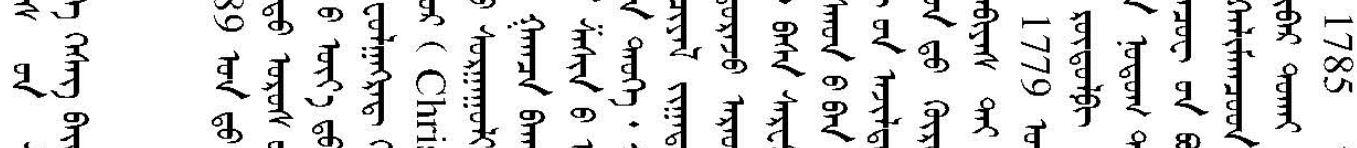

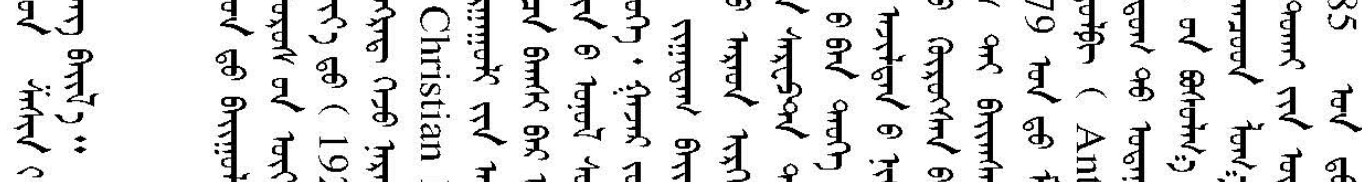

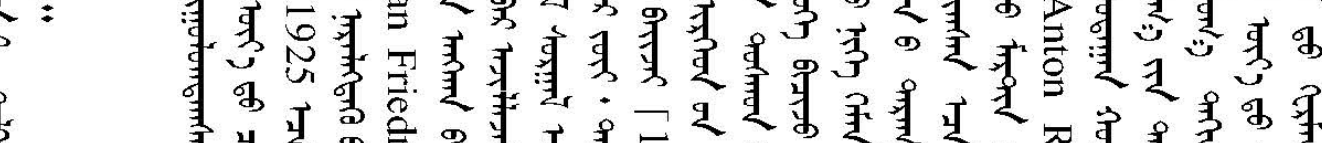

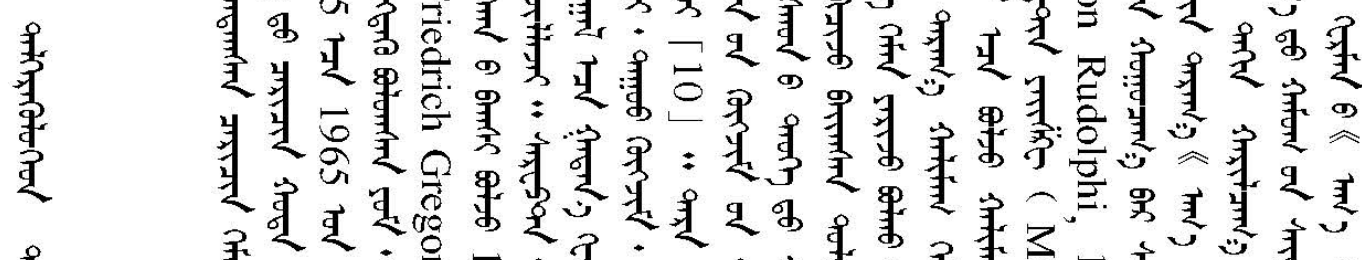

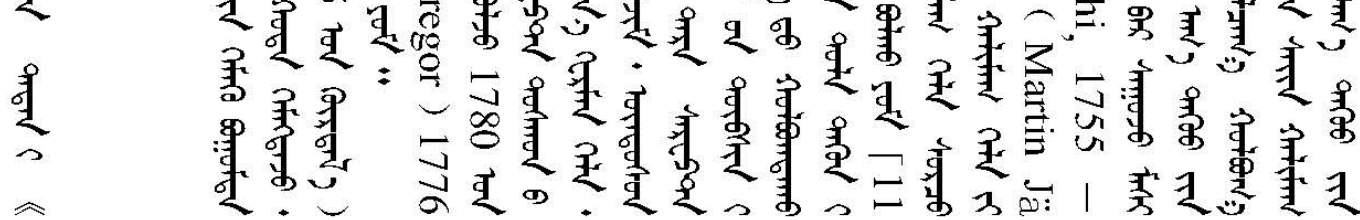

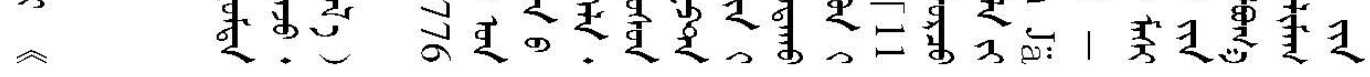

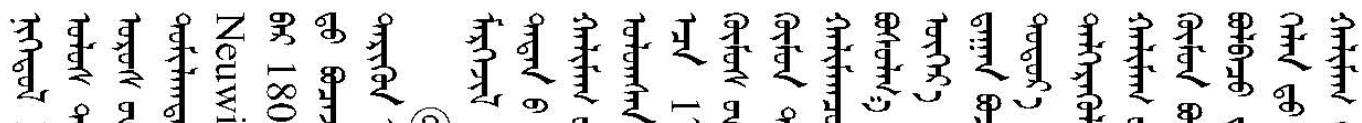

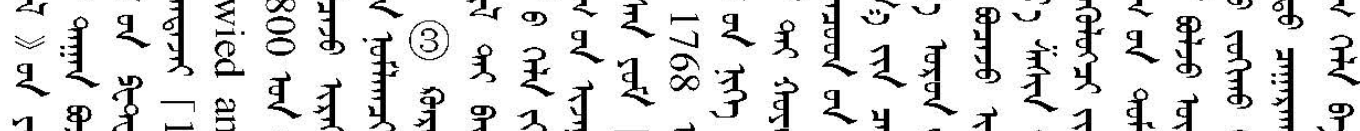

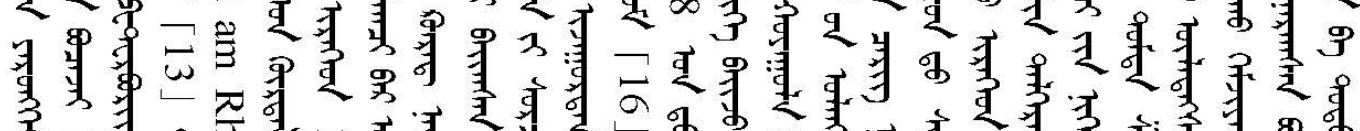

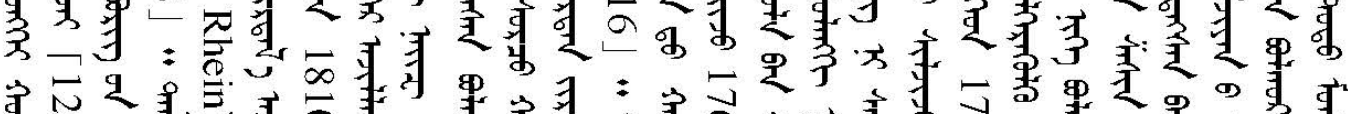

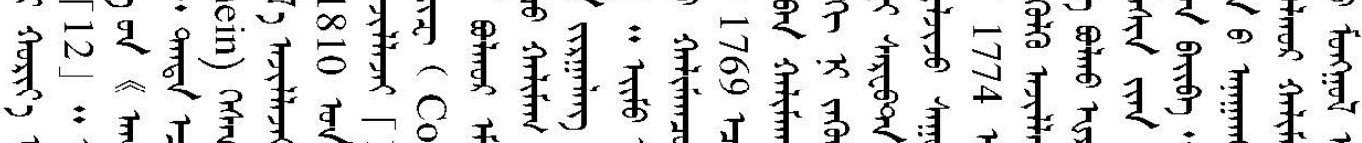

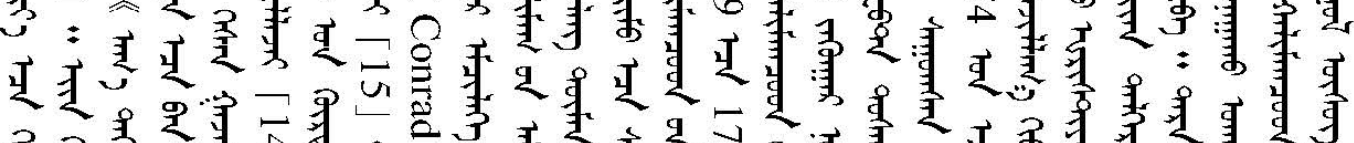

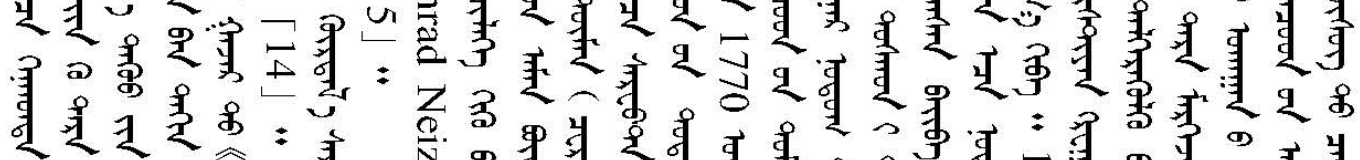

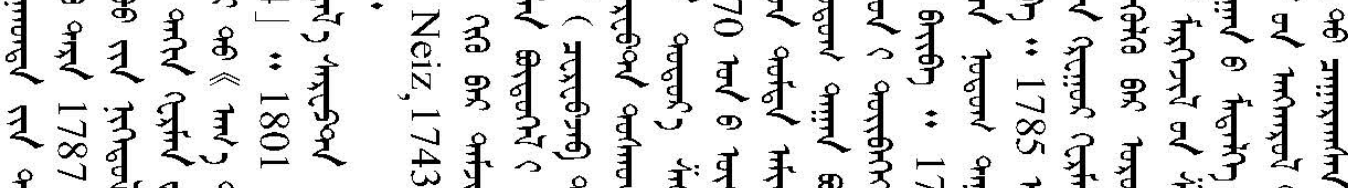

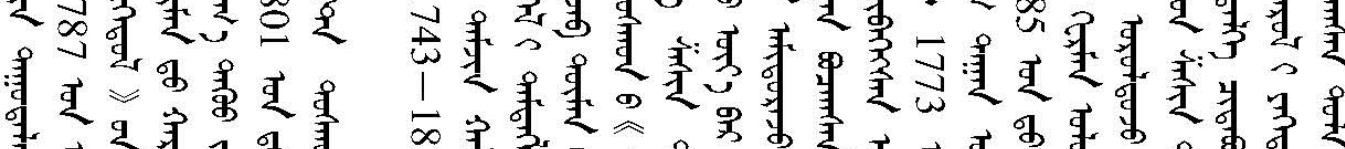

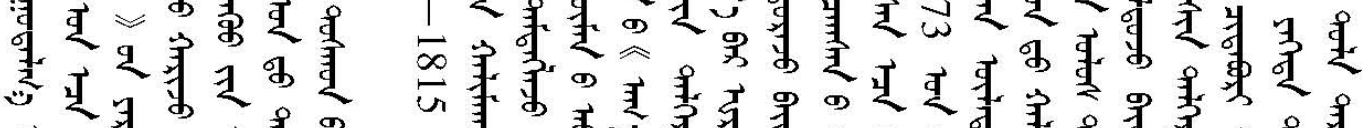

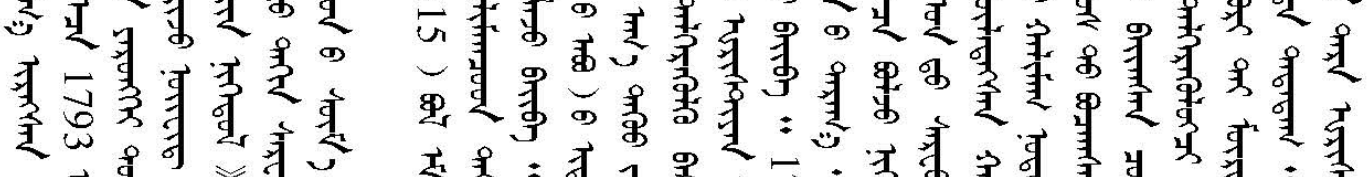

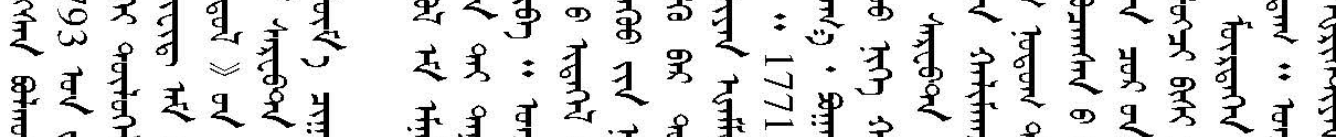

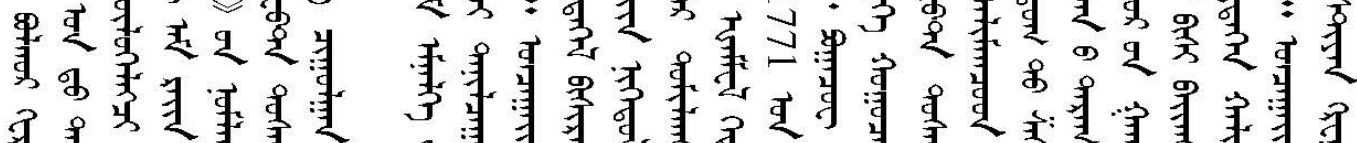

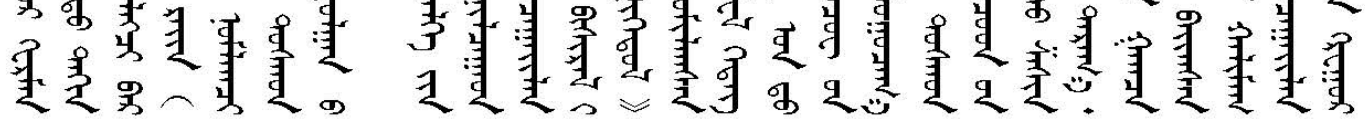



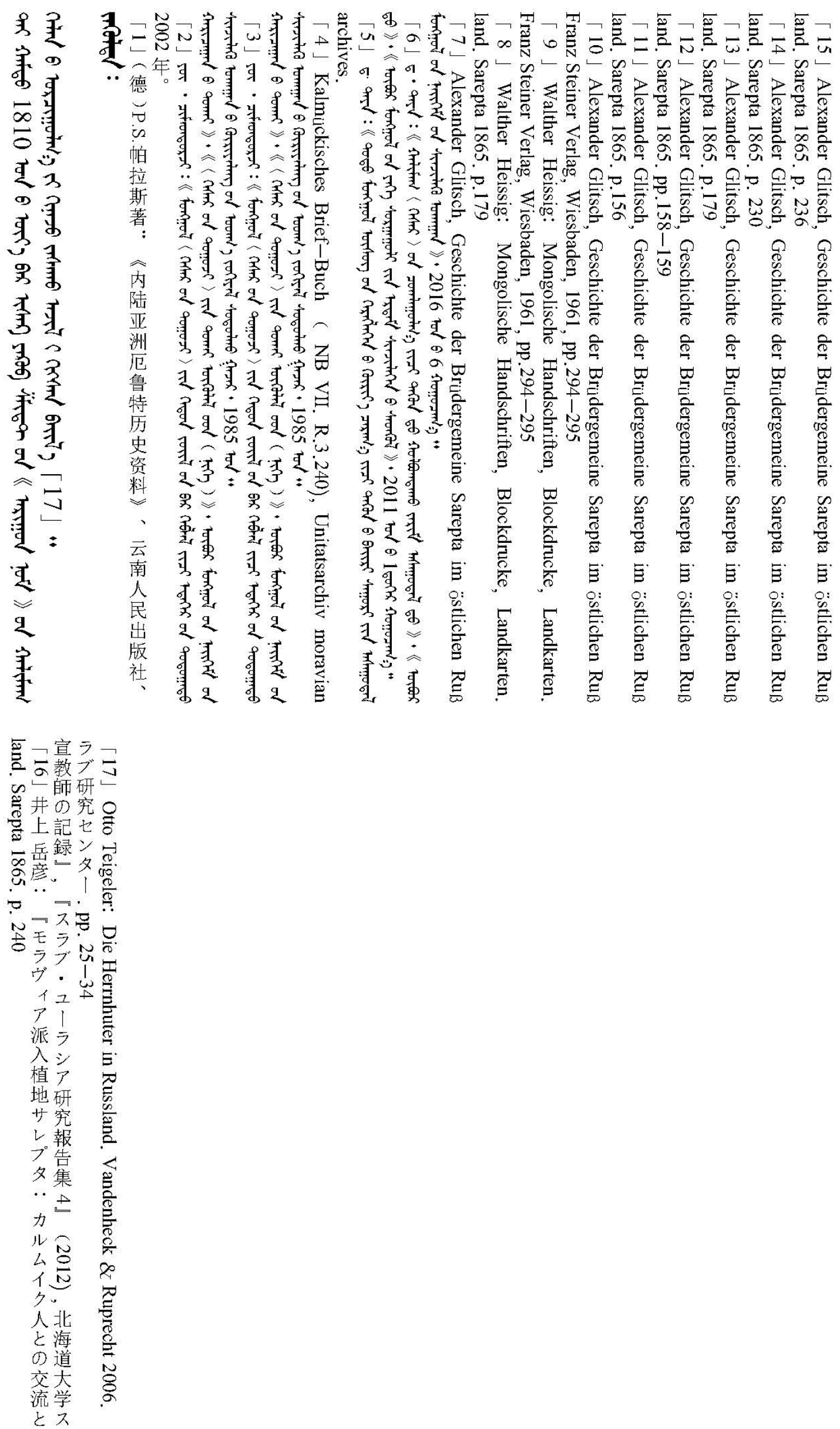